\title{
THE WEST WATER FORMATION (HUALAPAI PLATEAU, ARIZONA, USA) AS A CALCRETE- PALEOSOL SEQUENCE, AND ITS IMPLICATIONS FOR THE PALEOGENE-NEOGENE EVOLUTION OF THE SOUTHWESTERN COLORADO PLATEAU
}

\author{
Carol A. Hill ${ }^{a,}{ }^{,}$, Victor J. Polyak ${ }^{a}$, David J. Nash ${ }^{b, c}$, Yemane Asmerom ${ }^{a}$, Paula P. Provencio a \\ ${ }^{a}$ Earth and Planetary Sciences, University of New Mexico, 221 Yale Blvd., Albuquerque, NM, 87131, USA \\ ${ }^{b}$ School of Environment and Technology, University of Brighton, Lewes Road, Brighton BN2 4GJ, UK \\ 'School of Geography, Archaeology and Environmental Studies, University of the Witwatersrand, Private \\ Bag 3, Wits 2050, South Africa \\ * Corresponding author at: Earth and Planetary Sciences, University of New Mexico, 221 Yale Blvd., \\ Albuquerque, NM, 87131, USA. Email address: carolannhill@aol.com (C.A. Hill).
}

ABSTRACT. Analyses of stratigraphic sequences within the paleocanyons of the Hualapai Plateau, Arizona, are important because these deposits offer the only evidence for the Paleogene-Neogene geological history of the Grand Canyon area. In this paper, we focus on the origins and paleoenvironmental significance of the West Water Formation, located within the Milkweed and West Water paleocanyons on the Hualapai Plateau. We propose that the supposed "limestone unit" of the West Water Formation at and near its type section is not a limestone; rather, it is a $21 \mathrm{~m}$-thick valley calcrete, overprinted by a 1-2 m-thick pedogenic calcrete, and subsequently dolomitized in its upper-to-middle sections, with a superimposed 4 $\mathrm{m}$-thick red paleosol. We also propose that this unit is not coeval in age or origin with the Long Point limestone on the Coconino Plateau, and that the presence of a complex calcretedolocrete-paleosol alters previous interpretations associated with this unit. Evidence for a calcrete-paleosol origin, beyond the West Water Formation's lack of fossils, includes: its predominantly micritic calcite-palygorskite composition; its textures characteristic of valley and pedogenic calcrete deposits (as exhibited by thin section, SEM, and TEM analyses); and its association with a relatively thick overlying red paleosol that also contains abundant palygorskite. Stable carbon and oxygen isotope values from carbonate cements are also within the range expected of a near-surface calcrete. Carbonate minerals within the calcrete-dolocrete were precipitated at or near the water table in a valley setting due to evaporation and/or $\mathrm{CO}_{2}$ degassing in a semi-arid to arid environment of deposition. High ${ }^{87} \mathrm{Sr} /{ }^{86} \mathrm{Sr}$ values within the calcrete were inherited from groundwater infiltrating through Music Mountain Formation arkosic sediments, which were derived from a Precambrian source terrane to the south and 
southwest. No absolute ages exist for the Music Mountain Formation and West Water Formation in the Milkweed and West Water paleocanyons; these sediments could range in age from the Late Cretaceous to the latest Eocene-earliest Oligocene, and may record the EoceneOligocene Transition in the Grand Canyon area.

KEYWORDS. Calcrete; dolocrete; paleosol; Grand Canyon; Hualapai Plateau; Eocene-Oligocene Transition 


\section{INTRODUCTION}

A growing body of evidence for early-Laramide uplift, unroofing, and paleocanyon incision in the Grand Canyon region of the southwestern Colorado Plateau, Arizona, USA, has allowed for the development of numerous different evolutionary interpretations of Grand Canyon (Hill et al., 2016). One area of debate centers upon evidence from the Hualapai Plateau, the southwesternmost plateau of the Grand Canyon region (Fig. 1). Here, early-Laramide unroofing exposed the Redwall Limestone as the top unit over much of the Hualapai Plateau surface, rather than the Kaibab Limestone that occurs on the Coconino Plateau and across the rest of the Grand Canyon area. This suggests that the Hualapai Plateau uplifted earlier than the rest of the Grand Canyon region ( 85-80 Ma) (Flowers et al., 2008).

The study of the stratigraphic sequence of deposits within the paleocanyons of the Hualapai Plateau is important because it offers the only evidence of what was happening during the Paleogene and Neogene in the Grand Canyon area. During the earliest phase of uplift of the Hualapai Plateau, deep ( 1200-1600 m) paleocanyons became incised into what is now the plateau surface, to be later partially filled with as much as $450 \mathrm{~m}$ of deposits (Young, 1982, 2001b; Wernicke, 2011; Flowers and Farley, 2012). The oldest of these canyon deposits is called the Music Mountain Formation, a series of arkosic gravels and sandstones that were derived from the Mogollon Highlands/Kingman Uplift to the south and southwest (Young and McKee, 1978; Young, 2001b, 2007; Young and Hartman, 2014). Reportedly interbedded with the Music Mountain Formation is the Hindu Fanglomerate, which formed as debris flows, avalanche deposits, and mass-wasted colluviums off the edge of infilling paleocanyons (Young, 1999; Fig.

2). Conformably overlying the top of the Music Mountain Formation in Peach Springs, Milkweed, and West Water canyons on the Hualapai Plateau is the West Water Formation (Young, 1966, 1999), which reportedly consists of a "limestone unit" and overlying reddened 
silt-and clay-rich sediments. The West Water Formation is in turn overlain unconformably by the conglomeratic Buck and Doe Formation and subsequent volcanics (Fig. 2). A complete description of the stratigraphy of this area is provided by Young and Crow (2014) and Young and Hartman (2014).

The Music Mountain Formation additionally occurs on the Coconino Plateau, but as a surface and shallow lake deposit rather than as a deep canyon deposit. This occurrence crops out in the area of Long Point (Fig. 1), where it directly overlies either the Permian Kaibab Limestone or remnants of the Triassic Moenkopi Formation. The Music Mountain Formation arkosic gravels at Long Point are interbedded with a lacustrine, fossiliferous limestone unit called the Long Point limestone (Young, 1982). Hill et al. (2016) obtained a U-Pb date for the Long Point limestone of $64 \pm 2 \mathrm{Ma}$ at Duff Brown Tank, Coconino Plateau, which is reportedly age-equivalent to the interbedded Music Mountain Formation at this site. This absolute date is older than the early Eocene age assigned to the Long Point limestone by Young and Hartman (2014) on the basis of charophyte, ostracod, and viviparid gastropod fossils.

The limestone unit of the West Water Formation within the canyons of the Hualapai Plateau has long been regarded as age-equivalent to the Long Point limestone on the Coconino Plateau, based on sediment descriptions and on the assumption that the two plateau units were deposited as coeval lacustrine limestones (Lucchitta and Young, 1986; Young, 2001b, 2007; Young et al., 2011). The two units are now considered to be of slightly different ages: Young and Hartman (2014, their Fig. 3) assigned an Early-Middle Eocene age to the West Water Formation based on stratigraphic and other relationships, and an Early Eocene age to the Long Point limestone based on fossil evidence. However, despite this assigned Early-Middle Eocene age for the West Water Formation, precise and accurate ages for the Music Mountain Formation and West Water Formation in Peach Springs, Milkweed and West Water canyons on the Hualapai 
Plateau are still lacking. The age of the Buck and Doe Formation is Oligocene, based on a $24.12 \pm$ 0.04 Ma date for an ash bed at the very top of the formation (Young et al., 2011; Young and Crow, 2014; Young and Hartman, 2014); however, the age of the lower part of the Buck and Doe Formation is not known, since a disconformity exists between it and the top of the West Water Formation (Fig. 2). The Peach Springs Tuff, immediately above the Buck and Doe Formation, has been dated at $18.78 \pm 0.02$ Ma near its source at Silver Creek Caldera $\sim 50 \mathrm{~km}$ to the southwest (Ferguson et al., 2013); one of the Miocene basalts above the tuff has been dated to $18.13 \pm$ 0.04 Ma (Dominguez et al., 2012; Young and Hartman, 2014) (Fig. 2).

Establishing the mode of origin and timing of development of the West Water Formation is key to understanding conditions during the latter stages of the Music Mountain Formation interval, and hence to evolutionary interpretations of the western Grand Canyon. In this study we characterize the West Water Formation at two locations on the Hualapai Plateau, one in West Water Canyon and one in Milkweed Canyon (Fig. 1, lower inset, Sites 1 and 2, respectively), using a variety of petrological, mineralogical and geochemical techniques. From our results, we challenge the long-standing proposition that the West Water Formation is a lacustrine limestone at these sites, and provide evidence for it instead being a part-dolomitized valley calcrete, developed within the upper sections of the Music Mountain Formation, with a superimposed dolomitized pedogenic calcrete, and overlying paleosol. This new interpretation has important implications for understanding the timing of paleocanyon infilling, as it makes any assumption of the age of the West Water Formation contentious. All that can be stated with certainty is that the West Water Formation is older - and perhaps much older - than the overlying, Oligocene Buck and Doe Formation. Our identification of the West Water Formation lacustrine limestone as a calcrete also has the potential to shed new light on geomorphological, climatological, and tectonic interpretations related to the Grand Canyon region. 


\section{PAST WORK}

\subsection{West Water Formation, Hualapai Plateau}

The West Water Formation was first informally called the "Westwater formation" by Young (1966) for excellent exposures in Milkweed and West Water canyons on the Hualapai Plateau. However the spelling of the name was later formally changed by Young (1999) to "West Water Formation" for West Water Canyon on Billingsley et al.'s (1999) geologic map (Fig. 1, lower inset). The West Water Formation consists of two distinct informal members: (1) a massive, well-indurated, white carbonate unit (herein referred to as the "massive calcareous unit"), overlain by (2) a relatively impermeable, reddish silt- to clay-rich unit (herein referred to as the "red-soil unit") that can cause seeps to form at the base of the overlying Buck and Doe Formation (Young, 1966, 2001a, b; Young and Crow, 2014). The red-soil unit was described by Young and Hartman (2014) as a "paleosol", which marks a disconformity between the top of the West Water Formation and the overlying Buck and Doe Formation.

The massive calcareous unit is best exposed in West Water Canyon near its confluence with Milkweed Canyon, where it is about $15 \mathrm{~m}$ thick (Fig. 3), and in the central part of Milkweed Canyon, where it is up to $21 \mathrm{~m}$ thick (Fig. 4). In Peach Springs Canyon, the West Water Formation reportedly consists mainly of the red-soil unit, but it also displays some discontinuous lenses of marl 15 to $30 \mathrm{~cm}$ thick; in Hindu Canyon it is reported as only the red-soil member, reaching $\sim 30 \mathrm{~m}$ in thickness; and in Bridge Canyon, the red-soil unit is reportedly up to $10 \mathrm{~m}$ thick (Young, 1966). The massive calcareous unit also reportedly occurs in the subsurface beneath the town of Peach Spring, AZ (Fig. 1), as recorded in four logs where it is up to $118 \mathrm{~m}$ thick (Young, 1979). All four logs show the calcareous unit overlain by the conglomeratic Buck and Doe Formation, with no red-soil unit separating these two formations. 
Elevation differences exist between the West Water Formation in West Water Canyon, Milkweed Canyon, and Peach Springs Canyon. Our Milkweed Canyon and West Water Canyon collection sites (Fig. 1, lower inset, Sites 1 and 2) are at 1263 m and 1227 m elevation, respectively, while West Water Formation outcrops in Peach Springs Canyon are at $\sim 1400 \mathrm{~m}$ elevation, possibly attesting to minor fault displacements within the study area, slumping, or different depositional elevations. Slumping and landslide deposits are profuse on the Hualapai Plateau (Billingsley et al., 1999), so many of the West Water Formation outcrops, such as the West Water site (Fig. 3), may have undergone displacement from their original positions.

According to Young (1966), the massive calcareous unit of the West Water Formation is both gradational and conformable with the underlying Music Mountain Formation. In the type section for the West Water Formation in Milkweed Canyon (Fig. 2), the Music Mountain Formation grades from coarser (gravel) to finer (sand) detrital material, and at its contact with the West Water Formation it is mostly sand. The contact between the two formations is $12 \mathrm{~m}$ thick, with reddish brown arkosic Music Mountain Formation sediments grading upward into white, calcite-enriched zones occurring as distinct bands or concretionary layers; these zones become predominant just below the massive calcareous unit. The contact of the massive calcareous unit with the overlying red-soil unit appears sharp, but could partly correspond to the amount of weathering and erosion the sequence has experienced (Fig. 3). In comparison to the underlying Music Mountain Formation and overlying Buck and Doe Formation, both the massive calcareous and red-soil units contain very few pebbles at both sites studied.

To our knowledge, there are no stable isotope analyses published for the West Water Formation, other than those of Huntington et al. (2010) from a single sample close to our Milkweed Canyon sampling site. They reported one carbon and oxygen stable isotope value as part of a clumped isotope analysis, where a carbonate formation temperature of $47.1 \pm 3.5^{\circ} \mathrm{C}$ 
was measured for the fluvio-lacustrine West Water Formation; stable isotope values from that analysis are $\delta^{13} \mathrm{C}=-4.5$ and $\delta^{18} \mathrm{O}=-5.3 \%$ (PDB).

\subsection{Valley and channel calcretes}

Much of the literature on calcrete - a general term given to near-surface, terrestrial accumulations of predominantly calcium carbonate which occur in a variety of forms from powdery to nodular, laminar and massive (Wright and Tucker, 1991) - focuses on pedogenic calcretes. Such deposits owe their origins to the accumulation of mainly atmospheric-derived bicarbonate by eluvial-illuvial processes related to soil formation, and are widespread in semiarid and arid regions, including large areas of the western USA (Wright, 2007). Calcretes can, however, occur in a variety of other forms and develop by other mechanisms (Carlisle, 1983). Of particular interest for this study are the various non-pedogenic calcretes developed around the water table-capillary fringe (or below) within (paleo) drainage features. These are often grouped together as "groundwater calcretes." However, as Nash and McLaren (2003) argue, this term is not particularly helpful, frequently being applied to any calcrete that has developed just above, at, or below the water table. These authors instead suggest that distinct types of non-pedogenic calcrete should be recognized on the basis of the geomorphological setting in which carbonate accumulation took place.

Two of the variants of "groundwater calcrete" are channel and valley calcretes (Carlisle, 1983), formed in association with (paleo) channels and (paleo) valleys, respectively. Channel calcretes can be defined as calcium carbonate accumulations that cement sediments immediately above, at or below the water table in confined impermeable bedrock channels (Nash and McLaren, 2003). They are variable in size and shape, reaching up to several meters thickness, but, critically, cement the full channel cross-section (see Maizels, 1990a,b; Rakshit 
and Sundaram, 1998; Nash and Smith, 1998, 2003; Mack et al., 2000; McLaren, 2004 for examples). Valley calcretes also accumulate immediately above, at or below the water table, but more typically cement sediments within much broader valleys. In contrast to channel calcretes, they rarely occupy the entire valley width or full thickness of alluvial fill, often exhibiting undulating surfaces, and 'pinching out' laterally at distance from the valley axis (cf. Miller, 1937; Netterberg, 1969; Carlisle et al., 1978; Mann and Horwitz, 1979; Carlisle, 1983; Reeves, 1983; Kaemmerer and Revel, 1991; Butt, 1992; Nash et al., 1994; Nash and McLaren, 2003). The bestdeveloped valley calcretes within Australian and Kalahari paleodrainage systems reach up to 10 km width, 100 km length, and several tens of meters in thickness (Arakel and McConchie, 1982; Arakel, 1986, 1991; Jacobson et al., 1988; Arakel et al., 1989; Nash et al., 1994).

The climatic controls upon channel and valley calcrete formation are not fully understood, but, like pedogenic calcrete, both appear to be best-developed in semi-arid to arid regions. In both types, a minor proportion of the carbonate may be supplied via atmospheric input, but the main carbonate source is shallow groundwater moving laterally into and along the channel/valley. As with pedogenic calcrete, evaporation or evapotranspiration may be important mechanisms triggering carbonate precipitation in near-surface sediments, but $\mathrm{CO}_{2}$ degassing associated with a fluctuating water table is likely to be more significant at depth (Nash and McLaren, 2003; Nash and Smith, 2003). Studies of valley calcretes within Australian paleodrainage systems suggest that the thickest calcretes form within the zone of groundwater fluctuation, with their thickness attributed to progressive carbonate accumulation associated with a fluctuating but gradually falling water table (Arakel and McConchie, 1982; Arakel, 1986, 1991; Jacobson et al., 1988). Valley calcretes may not be uniform in thickness. Australian examples have been suggested to have initiated as a series of isolated calcrete pods and domes 
prior to the more extensive cementation of a valley fill, with subsequent carbonate precipitation causing expansion and uplift (cf. Mann and Horwitz, 1979).

The rate of development of calcrete sequences is highly variable, and is dependent upon the interplay between climatic conditions and carbonate supply (which, of course, may change over time; Wright, 2007). Based on reliably dated Quaternary calcretes, well-developed (i.e. greater than stage 4; see Machette, 1985) pedogenic calcretes of up to a few meters thickness may take anywhere between $3 \mathrm{ka}$ and $1 \mathrm{Ma}$ to form (Wright and Tucker, 1991) - more than two orders of magnitude variation. To date, no studies have constrained the time required for either valley or channel calcrete development. Given the likely more rapid supply of carbonate via groundwater as opposed to atmospheric inputs (Wright, 2007), it would be expected that a channel or valley calcrete would form more quickly than a pedogenic calcrete of equivalent thickness. Regardless, a valley calcrete tens of meters in thickness still must take at least several hundred thousand years to develop.

There have been relatively few analyses of the micromorphology of either channel or valley calcretes. Those studies that have been undertaken suggest that, in contrast to pedogenic calcretes, valley calcretes are dominated by non-biogenic, alpha-fabric assemblages at the microscale (Wright, 2007; Wright and Tucker, 1991). Typical fabrics are comprised mainly of dense crystalline groundmasses of simple micrite and microspar, with nodular structures and complex networks of cracks common (e.g. Nash and McLaren, 2003). Microspar and even sparry calcite may occur within cracks, void spaces between nodules, and in areas of fenestral porosity; these more crystalline cements suggest periods of longer porewater residence within the developing calcrete groundmass (McLaren, 1993). More complex fabrics have been documented where, for example, pedogenic calcrete formation has occurred close to the land surface immediately above a developing (or fully developed) valley or channel calcrete, or a valley 
calcrete that has been exposed by erosion. This may lead to mixed alpha and biogenic (beta) fabrics in the uppermost sections of the resulting calcrete profile, with features such as microbial coatings, calcified tubules, calcified pellets and plant cells, spherulites, and alveolar septal structures present in addition to the alpha-fabric features noted above (cf. Nash and Smith, 1998; Nash and McLaren, 2003; Wright, 2007).

Little information is available on the stable isotopic signature of channel or valley calcretes. The range of influences on the isotopic composition of present-day pedogenic calcretes is large, as is the potential for the resetting of isotopic signatures over time due to diagenesis (see Wright, 2007 for a review). Commonly observed $\delta^{13} \mathrm{C}$ values for primary soil carbonates range from -14 to $+4 \%$. VPBD, and $\delta^{18} \mathrm{O}$ values from -20 to $+10 \%$ ㄱPBD (Leier et al., 2009); $\delta^{13} \mathrm{C}$ and $\delta^{18} \mathrm{O}$ values for pedogenic calcretes typically fall within the more negative parts of these ranges (cf. Talma and Netterberg, 1983; Tandon and Andrews, 2001; Adamson et al., 2015). Calcretes cemented via groundwater are likely to exhibit heavier $\delta^{13} \mathrm{C}$ values, provided the carbonate was precipitated below the main zone of root activity and organic decomposition (Wright and Tucker, 1991). They might also be expected to exhibit more evolved $\delta^{18} \mathrm{O}$ values. A possible exception to this is where rapid infiltration of rainfall has occurred due to storm events, whereby groundwater carbonates may exhibit lighter oxygen isotope values than pedogenic varieties (Wright and Tucker, 1991).

\section{RESULTS}

Samples of the West Water Formation were collected at two sites: from West Water Canyon (Fig. 1, lower inset, Site 1; also Young, 2011, his Fig. 13), and Milkweed Canyon (Fig. 1, lower inset, Site 2; the type section for the Music Mountain Formation, Young, 1966). At the West Water Canyon site (N35 $\left.38^{\prime} 44.5^{\prime \prime}, \mathrm{W} 113^{\circ} 41^{\prime} 28.1^{\prime \prime}\right)$, the massive calcareous unit is $15 \mathrm{~m}$ thick 
and the overlying red-soil unit is $\sim 10 \mathrm{~m}$ thick (Fig. 3). Five samples of the massive calcareous unit were collected at $\sim 3 \mathrm{~m}$ intervals. At the Milkweed Canyon site (N35 $38^{\prime} 42.9^{\prime \prime}, \mathrm{W} 113^{\circ} 41^{\prime}$ 43.4"), the massive calcareous unit is $\sim 21 \mathrm{~m}$ thick, and the red soil unit is $\sim 4 \mathrm{~m}$ thick (Fig. 4 and Young and Hartman, 2014; their Fig. 2). Two profiles were sampled at this site on two separate visits. At profile 1, one sample was collected from the red-soil unit, with a further six samples from the massive calcareous unit (at depths of 3.0, 4.3, 5.5, 9.1, 14.6, and $18.3 \mathrm{~m}$ from the top of the outcrop). At profile 2, one sample was collected from the red-soil unit, and eight samples from the massive calcareous unit (at depths of $0,3,6,9,12,15,18$, and $21 \mathrm{~m}$ below the contact with the red-soil unit). In addition, one sample of fine-grained matrix material from the Hindu Fanglomerate $\left(\mathrm{N} 35^{\circ} 38.6^{\prime}, \mathrm{W} 113^{\circ} 40.85^{\prime}\right)$ and two samples of Music Mountain Formation intergravel matrix material (N35 $\left.38.6^{\prime}, \mathrm{W} 113^{\circ} 41.0^{\prime}\right)$ were collected in Milkweed Canyon (Fig. 1, lower inset).

Samples collected from these sites were analyzed using a variety of methods to establish their micromorphology, mineralogy, elemental composition, and strontium (Sr)isotope systematics (see Table 1 for details). These methods included qualitative thin-section analysis (of both standard and Alizarin Red stained sections), scanning electron microscopy (SEM), X-ray powder diffraction (XRD), transmission electron microscopy (TEM), energydispersive X-ray spectroscopy (EDS), inductively coupled plasma mass spectrometry (ICP-MS), stable carbon and oxygen isotope analysis, and strontium-isotope geochemistry, all undertaken at the University of New Mexico and University of Brighton. The data described below supports our interpretation for the Milkweed and West Water canyon carbonate exposures as primarily valley calcrete profiles. 


\subsection{Petrographic characteristics}

Samples of the West Water Formation from both the Milkweed and West Water canyon collection sites were examined in thin-section (Fig. 5) to establish their micromorphology and the sequence of development of cements and other grain-coatings. Samples from Milkweed Canyon were additionally analyzed by SEM (Table 1). Analyses reveal an abundance of angular to sub-rounded detrital grains within both the red-soil and all samples of the massive calcareous unit. These grains consist mostly of quartz, with feldspar common but minor. Some of the quartz grains appear to be etched, suggesting dissolution. With the exception of pebbles present in the middle section of the Milkweed Canyon site, and $\mathrm{cm}$-scale patches of coarse sand-sized grains within one sample (Fig. 5j; associated with a $20 \mathrm{~cm}$ thick granule-rich layer from towards the base of the massive calcareous unit in Milkweed Canyon), detrital grains throughout both units of the West Water Formation are dominated by silt-sized fractions. Taken as a whole, this suggests that both the red-soil and carbonate units shared common host sediment. At both the Milkweed Canyon and West Water Canyon localities, the abundance of detrital grains seems to decrease towards the very top of the calcareous member.

Thin-sections from the red-soil unit at both sites reveal the material to be strongly redcolored, with abundant pedogenic structures present, including glaebules and other microaggregates of clay minerals, and cutans lining some void spaces (Fig. 5a-c). Patches of late-stage microspar cement were also observed, mainly filling cracks and small voids, but calcite appears to comprise only a minor constituent of the red-soil unit overall. SEM observations show that the matrix consists of fibrous palygorskite crystals mixed with clay-like materials; the mineralogy of these materials is confirmed by XRD and TEM, as discussed in section 3.2.

The cement component of the massive calcareous unit of the West Water Formation, in contrast, is dominated by microcrystalline carbonate. Inspection of standard (Fig. $5 d-j$ ) and 
Alizarin Red stained (Fig. 6a) thin-sections, SEM analyses (Fig. 7a-c), whole rock XRD analyses

(Fig. 6c), and ICP-MS elemental concentrations (Table 2), confirm calcite as the main cementing agent throughout the basal-to-middle sections of the sampled profiles. While nodular structures were not observed in outcrop, microscale $(<3 \mathrm{~mm})$ coalescing irregular to spherical pelloidal and nodular features are abundant in thin sections from all samples, from the bottom to the top of this unit. In the majority of cases these are structureless and not suggestive of formation in a pedogenic setting (e.g. Fig. 5g). An exception is the uppermost sample from Milkweed Canyon profile 2 (immediately below the contact with the red-soil unit) where there is evidence of pedogenesis in the form of weakly-developed pedogenic glaebular structures (Fig. 5d-f). XRD (Fig. 6c) and ICP-MS (Table 2) analyses of an equivalent sample from profile 1 at this site (sample WWLS-MW6) indicate that dolomite is the main cementing mineral. Dolomite is also identified in stained thin-section (Fig. 6b) and by ICP-MS (Table 2) in two samples from the middle and top of the West Water Canyon profile (WWLS-WW3 and WWLS-WW5, respectively). Thin-section evidence suggests that, where present, dolomite has replaced pre-existing calcite rather than forming as a primary precipitate. Patches of microspar are present in all samples, mainly along cracks, within void spaces between nodular features, and in areas of fenestral porosity, suggesting late-stage emplacement. The proportion of microspar, and the size of individual patches, varies throughout samples from both sites, with greater proportions of microspar and in some cases sparry calcite cement towards the base of the member (Fig. 5i,j). Thin-section images further show that many quartz and clastic grains have been partially replaced by micrite or microspar, and in some cases, only ghosts of pre-existing grains exist. As with the overlying red-soil unit, SEM indicates the occurrence of palygorskite fibers throughout the massive calcareous unit, mainly around host sediment grains and within micropores (Fig. 7d). 
Thin-section analysis also provides insights into the relationship between the massive calcareous unit and the red-soil unit. Some clasts within the massive calcareous unit have redbrown mineral grain coatings when examined in thin-section, identified as fibrous palygorskite under SEM. This is more common in samples from the West Water Canyon site and the upper sections of Milkweed Canyon (profile 2). Ferri-argillan cutans and micro-aggregates of clay minerals are also present within cracks and lining the bottom of voids, in both the pedogenic and non-pedogenic carbonate phases (including dolomitized samples), suggesting gravitational accumulation (Fig. 5f). Microlaminar-like structures were further observed at the bottom of microspar-filled pores within some samples from the calcareous member at the West Water Canyon site. In combination, these features suggest illuviation of iron- and clay-minerals from the red-soil unit into the underlying massive calcareous unit largely after it had developed.

\subsection{Mineral assemblages}

As noted above, calcite was the main cementing agent of the massive calcareous unit in all three sampled profiles, with whole rock XRD and ICP-MS analyses confirming the presence of dolomite in the middle section of the West Water Canyon profile and upper section of Milkweed Canyon profile 1. XRD analysis of the clay fraction of the matrix $(<2 \mu \mathrm{m})$ of the red-soil unit from Milkweed Canyon profile 2 (Fig. 8a,b), further identified the presence of palygorskite $\left[(\mathrm{Mg}, \mathrm{Al})_{2} \mathrm{Si}_{4} \mathrm{O}_{10}(\mathrm{OH}) \cdot 4 \mathrm{H}_{2} \mathrm{O}\right]$, Fe-Mg-rich smectite, and minor/trace amounts of kaolinite, quartz, calcite, and mica. TEM (Fig. 9a) and XRD analyses indicate palygorskite and Fe-Mg-rich smectite as the most abundant crystalline constituents of the red-soil unit matrix, with minor Fe-oxide minerals present. It is likely that the red color of the red-soil unit is mostly derived from the smectite and Fe-oxides. The insoluble residue of one sample of the massive calcareous unit from Milkweed Canyon profile 2, which was dissolved in weak acetic acid, also contains 
abundant palygorskite (Fig. 9b). EDS analyses indicate that the palygorskite from both the redsoil unit and massive calcareous unit contains abundant Fe (Mg, Fe, Al-silicate), and that smectite in the insoluble residue is Fe-rich.

\subsection{Strontium-isotope geochemistry}

The Music Mountain Formation is presumed to be sourced from Precambrian-rich terranes to the south and southwest of the Grand Canyon region (Young and Hartman 2014; Hill et al., 2016). Therefore, like the Coconino Plateau Music Mountain Formation at the Duff Brown Tank site near Long Point (Fig. 1), sediments within the Music Mountain Formation and overlying West Water Formation on the Hualapai Plateau should also yield very high ${ }^{87} \mathrm{Sr} /{ }^{86} \mathrm{Sr}$ values (Hill et al., 2016). We measured ${ }^{87} \mathrm{Sr} /{ }^{86} \mathrm{Sr}$ values for samples of the red-soil unit (profile 1 ), massive calcareous unit (profile 1), Music Mountain Formation matrix and Hindu Fanglomerate matrix from Milkweed Canyon, and for samples of the massive calcareous unit from West Water Canyon (Table 1). Samples of the calcareous unit of the West Water Formation and the finefraction matrix of the Music Mountain Formation and Hindu Fanglomerate sediment were totally dissolved before separation chemistry. All samples yielded exceptionally high ${ }^{87} \mathrm{Sr} /{ }^{86} \mathrm{Sr}$ values of $\geq 0.719$ (Fig. 10). The highest values were from the Music Mountain Formation and Hindu Fanglomerate samples $(0.771,0.759$, and 0.726 , respectively). These high values support a Precambrian source. The ${ }^{87} \mathrm{Sr} /{ }^{86} \mathrm{Sr}$ values for the massive calcareous unit varied between 0.718 and 0.727 , while the value for the red-soil unit sample was 0.730 . The Sr standard run with the samples was NBS-987 and has ${ }^{87} \mathrm{Sr} /{ }^{86} \mathrm{Sr}$ value of 0.71025 . 


\subsection{Fossils}

We have observed no fossils other than microflora in the West Water Formation in the field, in hand specimen, in thin-section, or under SEM. A single, cm-long gastropod specimen of the freshwater genus Physa was reported by Young (1966) in the type section in Milkweed Canyon (similar to specimens at Long Point), but this was the only fossil found during Young's numerous visits to this and adjacent West Water Formation sections between 1962 and 1993 (Young and Hartman 2014). Young (1966) treated samples of the West Water Formation with $\mathrm{HCl}$ and found pollen or spores, which were unidentifiable because of the lack of pollen reference collections for Cenozoic rocks in the Grand Canyon area.

The five samples from the massive calcareous unit at the West Water Canyon site (Fig. 3) were analyzed for pollen by Owen Davis, palynologist, University of Arizona, Tucson. The concentration of pollen in all five samples was low: identified were one broken pine grain, two Asteraceae, six sagebrush/wormwood Artemisia grains, plus sunflower and grass. Davis (personal communication, 2012) considers these assemblages as "probably Pleistocene or Holocene," which suggests contamination of recent pollen down into small cracks within the massive calcareous unit. We found no pollen in these samples that would unequivocally date the massive calcareous unit to the Paleogene (that is, older than the uppermost 24 Ma-dated layer of the Buck and Doe Formation; Fig. 2).

\subsection{Carbon and oxygen stable isotope geochemistry}

Stable isotope values measured for samples WWLS-WW3 (mostly dolomite) and WW4 (mostly calcite) fall within the range expected for near-surface carbonates (see section 2.2). The stable isotope values for WW3 are $\delta^{13} \mathrm{C}=-7.5$ and $\delta^{18} \mathrm{O}=-7.7 \%$, and for WW4 are $\delta^{13} \mathrm{C}=-5.6$ and $\delta^{18} \mathrm{O}$ $=-8.2 \%$. The stable isotope values reported for the West Water Formation in Milkweed 
Canyon by Huntington et al. (2010) are $\delta^{13} \mathrm{C}=-4.5$ and $\delta^{18} \mathrm{O}=-5.3 \%$. For comparison, stable isotope values reported for the Long Point limestone, distinctly a lacustrine limestone, are $\delta^{13} \mathrm{C}=$ -6.6 and $\delta^{18} \mathrm{O}=-14.4 \%$ (Huntington et al., 2011).

\section{DISCUSSION OF DATA}

\subsection{The West Water Formation: a complex calcrete-dolocrete-paleosol sequence}

As noted in section 1, the calcareous unit of the West Water Formation in the Hualapai Plateau has long been considered a lacustrine limestone, age-equivalent to the Long Point limestone on the Coconino Plateau. Our new evidence from West Water and Milkweed canyons supports neither a lacustrine origin nor a coeval or near-age equivalence for these two deposits. Instead we suggest that the massive calcareous unit of the West Water Formation on the Hualapai Plateau originated mainly as a thick valley calcrete with a superimposed pedogenic calcrete (both dolomitized in parts, Fig. $3 \mathrm{~g}$ ), and that the red-soil unit overlying this calcrete-dolocrete sequence represents a subsequent paleosol. In contrast to the Long Point limestone on the Coconino Plateau, which is a light-grey fossiliferous sequence, the white massive calcareous unit of the West Water Formation in the Hualapai Plateau is essentially fossil-free. In addition, the abundance of detrital grains and clay minerals (palygorskite, smectite) within the calcareous unit on the Hualapai Plateau is distinct from the Long Point limestone on the Coconino Plateau, which is nearly pure calcite. This is further supported by the high ${ }^{87} \mathrm{Sr} /{ }^{86} \mathrm{Sr}$ values of the massive calcareous unit and overlying red-soil unit that exhibit values similar to the Music Mountain Formation (Fig. 10), unlike the Long Point limestone, which has significantly lower values than the Music Mountain Formation sediment on which it was deposited (Hill et al., 2016).

Our interpretation of the massive calcareous unit of the West Water Formation on the Hualapai Plateau as primarily a valley calcrete is based on its micromorphological characteristics; 
these match closely those of valley and channel calcretes documented elsewhere. The majority of samples are dominated by relatively simple, non-biogenic, alpha-fabric assemblages that comprise groundmasses of micrite and microspar, structureless peloidal/nodular features, and abundant networks of cracks (section 3.1). These are similar to fabrics described, for example, in Kalahari valley calcretes (cf. Nash and McLaren, 2003). Many cracks and void spaces between nodular features are filled by microspar, with sparite present in some voids towards the base of the exposures. The presence of more sparry cements within otherwise simple micritedominated fabrics is documented in a variety of groundwater calcretes (Tandon and Narayan, 1981; Nash and Smith, 1998; Mack et al., 2000). Similar vertical variability in calcite crystallinity has been described in channel calcretes in southeast Spain by Nash and Smith (2003), where it is suggested to be related to longer porewater residence times in lower sections of profiles. The partial replacement of quartz and other grains by micrite or microspar in some samples is also suggestive of longer periods of interaction between host sediments and circulating porewater solutions.

The bulk of the massive calcareous unit is interpreted as a valley calcrete rather than a channel calcrete on the basis that its relationship with the underlying Music Mountain Formation is gradational. In order to be a channel calcrete sensu stricto (see Nash and McLaren, 2003) it would need to fully cement either distinct paleochannels cut into the Music Mountain Formation or the entire paleocanyon fill. Further, the bulk of the massive calcareous unit is not a pedogenic calcrete since (a) no obvious laminar zone is evident at the top of either profile described, and (b) even though there are nodules present throughout both profiles, the majority lack obvious pedogenic structures. Pedogenic calcretes reaching the thickness of the profiles described here are extremely rare in the literature. Where they do occur they invariably comprise stacked sequences of calcrete profiles, representing alternating periods of calcrete 
formation and sediment accumulation, separated by laminar calcrete layers or paleosols. There is no indication of such breaks in profile development at either sampling site.

There is evidence from the uppermost sample from Milkweed Canyon (profile 2), that some pedogenic calcrete development took place at the top of the valley calcrete profile after the main phase of valley calcrete development. This produced a fused pedogenic/valley calcrete profile, with pedogenic glaebular structures overprinted onto the alpha-fabric valley calcrete groundmass. The spacing of samples from the massive calcareous unit precludes the direct measurement of the depth to which pedogenic calcrete penetrated into the valley calcrete. However, given the absence of pedogenic structures in thin-sections from the next sample down the calcrete profile, it is unlikely to have been more than 1-2 m thick. Overprinting of groundwater calcrete by pedogenic calcrete is not uncommon, particularly where the former has become exhumed as a result of surface erosion (cf. Khadkikar et al., 1998; Nash and Smith, 1998; Alonso-Zarza, 2003). Pedogenic calcrete emplacement may also explain the apparent decrease in the relative proportion of detrital grains present towards the very top of the massive calcareous unit, as expansion and grain displacement is widely documented in association with near-surface carbonate crystal growth (e.g. Buczynski and Chafetz, 2006). XRD and ICP-MS data suggest that, sometime after formation, the pedogenic calcrete and upper-tomiddle parts of the valley calcrete were dolomitized through the reaction of Mg-rich solutions with precursor calcite (cf. Arakel, 1986; Khalaf, 2007) to form a dolocrete.

The occurrence of various grain-coatings and cutans (plus micro-aggregates of clay minerals) as late diagenetic features within upper parts of the calcrete-dolocrete profiles suggests that formation of the red-soil unit was initiated towards the end of the period of calcrete development, sometime after dolomitization occurred, possibly under seasonal wet/dry conditions similar to those required for the formation of fersiallitic soils in mediterranean-type 
climates (Yaalon, 1997). Some of these grain-coatings, cutans and micro-aggregates may have accumulated under gravity as a by-product of soil development, while others, particularly the palygorskite grain coatings and pore-linings identified by SEM and XRD, may be more intimately linked to the latest stages of profile formation (or maturation). Palygorskite commonly forms in soils that are affected by rising Mg-rich groundwater and subject to strong and continuous evaporation (Singer, 1989), and it is also widely documented within calcretes (e.g. Goudie, 1983; Hay and Wiggins, 1980; Watts, 1980; Retallack, 1992; Rodas et al., 1994). Its relatively low stability limits its general distribution to soils in more arid areas (Singer, 1989).

Debates exist as to whether palygorskite is formed in situ during calcrete development or is inherited from the parent material. A number of studies have, however, shown that the alkaline medium provided by calcrete - a high pH (9 to 11), and high $\mathrm{Si}, \mathrm{Mg}$ and low Al activities in the soil solution - is particularly favorable to palygorskite neoformation (see Singer, 1989; Verrecchia and Le Coustumer, 1996). The presence of fibrous palygorskite grain coatings within the West Water Formation calcrete-dolocrete is strongly suggestive of neoformation, most likely concomitant with palygorskite-rich soil accumulation at the land surface. From thin-section evidence, at least some of the silica for the palygorskite may have been provided by the dissolution of feldspar and quartz host sediment grains within the calcrete (cf. Verrecchia and Le Coustumer, 1996), although dissolution of minerals such as smectite (Rodas et al., 1994), or an external silica source, is also possible. All of this evidence suggests the possibility that Fe-rich smectite $+\mathrm{Mg}+\mathrm{SiO}_{2}$ was transformed into palygorskite $+\mathrm{Fe}_{2} \mathrm{O}_{3}$ during neoformation due to solutions providing abundant magnesium, with silica supplied by the etching of quartz and/or dissolution of feldspars/clay minerals, and with iron oxide and Fe-rich smectite causing the vivid red color of the red-soil unit (Fig. 3). 


\subsection{Model of formation for the West Water Formation}

On the basis of the preceding text, we propose the following four-stage model (Fig. 11) for the development of the calcrete-dolocrete and overlying red-soil unit of the West Water Formation within the Hualapai Plateau:

Stage 1. A sequence of predominantly silt-sized sediments (with rare pebble-, granuleand coarse sand-rich layers) accumulated towards the end of the Music Mountain Formation interval within paleocanyons incised into the Hualapai Plateau. As noted in section 1, these Music Mountain Formation sediments were sourced from Precambrian-rich terranes to the south and southwest. The fine grain size suggests that sedimentation occurred in a lower energy setting than earlier components of the Music Mountain Formation, perhaps in either a lowgradient valley or playa-type environment, within an overall steep canyon setting. It is likely that the water table was below the base of these sediments for much of this time. The change in depositional regime from the gravel-rich Music Mountain Formation to the silt-dominated West Water Formation, if consistent from site to site, may offer clues to the environmental and depositional setting of these units. As is discussed in section 5.3 below, this change may not only reflect a less energetic final stage of deposition after the source area for the sediments was cut off, but it may also offer insights into the tectonics of the southwestern Grand Canyon in the Paleocene-Neogene.

Stage 2. During a sustained period of landscape stability, shallow Ca-rich groundwater flowed through the sediments deposited in Stage 1, with near-surface evaporation and $\mathrm{CO}_{2}-$ degassing at depth triggering calcium carbonate precipitation. High ${ }^{87} \mathrm{Sr} /{ }^{86} \mathrm{Sr}$ ratios of 0.718 to 0.727 within calcrete samples suggest that groundwater moved, at least in part, through the underlying arkosic Music Mountain Formation, which has higher values (0.759 to 0.771 ). Calcium carbonate accumulated initially as micritic nodules within the sediment body, with 
further micrite and microsparite progressively infilling inter-nodular voids and cracks. The small crystal size of the calcrete groundmass indicates relatively rapid precipitation, possibly from fluctuating groundwater under an arid climatic regime. However, there must have been periods of more prolonged wetting during which microspar and sparry cements developed within cracks and voids. Water table fluctuations over time, or, by analogy with Australian examples, a gradual fall in water table levels, led to the accumulation of a thick valley calcrete. The depth to which carbonate cementation occurred was limited by the depth of shallow groundwater penetration into the sediment sequence, to produce a diffuse boundary between the West Water Formation calcrete and the underlying sediments. Spatial variations in the thickness of the calcrete member across the Hualapai Plateau may be explained by the initial growth of calcrete pods and domes of varying thickness and extent close to the water table that coalesced as the valley calcrete developed (cf. Mann and Horwitz, 1979).

$\underline{\text { Stage } 3}$. Towards the end of the period of valley calcrete development - most likely following a fall in the water table to below the base of the West Water Formation - pedogenic calcrete formation occurred within the sediments immediately above the valley calcrete. This overprinted microstructures within the uppermost part of the valley calcrete profile. Landscape conditions must have remained stable during this time. Sometime after this, the pedogenic calcrete and upper-to-middle sections of the valley calcrete were dolomitized to form a dolocrete.

Stage 4. The red-soil unit accumulated above the fused pedogenic/valley calcretedolocrete profile, alongside palygorskite neoformation and the gravitational accumulation of ferran and ferro-argillan void linings in the uppermost sections of the calcrete. Magnesium for the palygorskite - and for the earlier replacement of the calcrete by dolomite - could have had its source in the dolomitic Muav Formation and/or Mg-rich minerals in the Music Mountain 
Formation. Silica for the palygorskite may have been supplied by dissolution of host sediments or clay minerals within the calcrete, or from external sources (possibly including windblown dust). Silica and iron oxides may also have been released during the transformation of smectite into palygorskite, leading to rubification of the red-soil unit.

The end product of this complex four-stage sequence was a composite calcretedolocrete profile of varying thickness, covered by a palygorskite-rich red paleosol, also likely of varying thickness, that reflected the surface topography of the cemented paleocanyon infill. The period of relative landscape stability and low sediment input associated with the West Water Formation calcrete-dolocrete and red soil continued until a change to higher energy conditions resulted in the disconformable burial of the West Water Formation and Music Mountain Formation by the gravels of the Buck and Doe Formation. In some areas, this may have resulted in the partial or total erosion/removal of the red-soil unit to leave only the underlying calcretedolocrete, or, in areas where the duricrust was less thick, it could have left mostly the red-soil unit along with remnants of marl.

In our study area, the Buck and Doe Formation and underlying units were subsequently blanketed by basalts and the Peach Spring Tuff from 19 to $18 \mathrm{Ma}$. This may have caused some heating of the West Water Formation, as possibly indicated by the clumped-isotope temperature of $47^{\circ} \mathrm{C}$ reported by Huntington et al. (2010) (see sections 2.1 and 3.5). The complex nature of the West Water Formation calcrete (diagenesis, dolomite abundance, clays, and possible amorphous silicate phases) may, however, have altered the results of this method. We favor the interpretation that the high clumped-isotope temperature, in addition to heating, is an indication of isotope resetting due to diagenesis (as Huntington et al., 2010, suspected), and, as such, is an additional indicator that the West Water Formation carbonate unit is a 
calcrete. Stable isotope values for the West Water calcrete (section 3.5) fall well within the range reported for soil carbonates in section 2.2 .

\section{AGE OF WEST WATER FORMATION}

As it now appears that the West Water Formation limestone unit is a complex calcretedolocrete, and is not equivalent to the Long Point limestone in age based on fossils and/or origin, this opens up the question of the age of the West Water Formation. Dating of the West Water Formation calcrete-dolocrete has proven problematic. An attempt to U-Pb date a calcrete sample from the West Water Canyon collection site containing the least amount of insoluble material failed, probably because of continuous exchange over time of $\mathrm{U}$ and/or $\mathrm{Pb}$, and maturation of the profile through recrystallization and dolomite replacement. We did not attempt paleomagnetism because our inability to correlate against absolute ages would have rendered such data meaningless. From our present knowledge base, the West Water Formation could be as old as the Latest Cretaceous or as young as Early Oligocene.

\subsection{Previous ideas}

Several studies (e.g. Young, 2007; Young et al., 2011; Young and Crow, 2014; Young and Hartman, 2014) have speculated on the age of the West Water Formation; however, all have based their age estimations on the premise of the massive calcareous unit being a lacustrine limestone. These studies considered that the Music Mountain Formation and West Water Formation both formed under subtropical to arid conditions, or as stated by Young and Hartman (2014, p. 885), “...the thick red paleosol development, lacustrine facies, and well preserved indigenous fossil logs in Peach Springs Wash indicate a more humid climatic regime that is incompatible with the onset of post-Eocene drier conditions documented throughout the 
western United States." Summarizing our understanding of this model: (1) The preserved logs that Young (2011, his Fig. 8) found in the middle of the Music Mountain Formation in Peach Springs Canyon probably document the more humid climate of, and prior to, the Eocene Climatic Optimum (Fig. 12); (2) the later Music Mountain Formation and West Water Formation probably formed under a subtropical climate with lateritic soil conditions; (3) the red-soil unit is significantly older than Oligocene (Young et al., 2011); and (4) the depositional hiatus ("disconformity" of Figs. 2, 10) took place in the Middle to Late Eocene(?) before the establishment of more arid conditions at the Eocene-Oligocene boundary.

The results presented in sections 3.1-3.5 reveal two major weaknesses in these models. First, as discussed above, the statement that a lacustrine facies is present within the West Water Formation on the Hualapai Plateau is incorrect. Second, there is no evidence that the red-soil unit is a lateritic soil. A number of observations support this latter assertion: (i) the red-soil unit incorporates silt-sized feldspars - these would normally be destroyed during lateritization along with other ferromagnesian minerals (Widdowson, 2007); (ii) while lateritic soils may contain clay minerals, they tend to be silica-depleted since silica is also leached out during lateritization - the abundance of palygorskite and smectite in our samples is incompatible with this; (iii) the red-soil unit does not exhibit micro-structures typical of indurated laterites (see McFarlane, 1976, 1983); (iv) there is no evidence from thin-sections for the extensive dissolution of the underlying calcrete that would be expected to arise from leaching associated with lateritic soil development. Clearly, an alternative age model for the West Water Formation is required; we evaluate two possible options below. 


\subsection{Age Model \#1 for the West Water Formation: Latest Cretaceous-Early Paleocene}

Our Model \#1 (Fig. 12, upper graph) assumes that the Music Mountain Formation on the Hualapai Plateau is age equivalent to the Music Mountain Formation on the Coconino Plateau (that was deposited near the Late Cretaceous/Paleocene boundary, based on Hill et al.'s (2016) 64 Ma date for the Long Point limestone facies on the Music Mountain Formation at Long Point). This model assumes that depositional rates of the Music Mountain Formation at these sites are similar to those measured by Cather et al. (2008) for the Paleocene-Eocene (65-177 $\mathrm{m} / \mathrm{Ma}$ ) on the Colorado Plateau. The Music Mountain Formation is $\sim 150 \mathrm{~m}$ thick on both plateaus at most sites, so any model having these assumptions would suggest that the Music Mountain Formation was deposited within a 2 Ma period around 64 Ma. Our Model \#1 seemingly portrays an unreasonable "long depositional hiatus" from 64 to 28 Ma for the West Water Formation, during which the thick, mature pedogenic/valley calcrete-dolocrete could have formed in episodes of semi-arid climate conditions on the Hualapai Plateau (Fig. 11). Long terrestrial depositional hiatuses are rare in the literature, most likely due to both their rarity and difficulty to identify. However, DeCelles et al. (2007) reported a 50 Ma depositional hiatus from Late Cretaceous to Eocene on the central Tibetan Plateau that was associated with high paleoelevation and aridity. A $36 \mathrm{Ma}$ depositional hiatus (i.e. from 64 to $28 \mathrm{Ma}$ ) in the area of western Grand Canyon would have major implications regarding the origin of a Cretaceous-aged Grand Canyon proposed by some researchers (Wernicke, 2011). For example, Model \#1 could correlate with greatly reduced scarp retreat rates during the proposed depositional hiatus. It would also have the pedogenic imprint onto the valley calcrete occur around the time of the Eocene-Oligocene Transition (EOT) and/or during other drier periods. 


\subsection{Age Model \#2 for the West Water Formation: Eocene-Oligocene Boundary}

Our preferred Model \#2 (Fig. 12, lower inset) proposes that the age of the West Water Formation on the Hualapai Plateau is Late Eocene to Early Oligocene; this is approximately commensurate with the EOT ( 35-32 Ma), when there was a global change to a cool, arid climate associated with the onset of the first Paleogene-Neogene Antarctic glaciation (DeConto and Pollard, 2003; Coxall et al., 2005). It is a reasonable assumption that our West Water Formation calcrete formed in an arid to semi-arid environment, since most known valley calcretes are suggested to have formed under these conditions, and since palygorskite in soils is usually considered to be an arid-climate indicator mineral. Further, Model \#2 considers Model \#1's 36 Ma duration to be an unrealistically long time for the build-up of $20 \mathrm{~m}$ of nonpedogenic calcrete under groundwater conditions; also that a very long depositional hiatus is less practical. This model suggests that a more reasonable time of deposition of the West Water Formation calcrete-dolocrete would be about $1 \mathrm{Ma}$.

A late Paleogene age for the calcrete may also possibly solve the mystery of why very few gravels act as host material for the calcrete-dolocrete and red-soil units. Their absence may favor the beginning of a period of regional tectonics ( 35-30 Ma) known as the "Mid-Tertiary Magmatism and Extensional Deformation" episode, that extended from about 35 to $10 \mathrm{Ma}$ (see Dickinson, 1989; Spencer and Reynolds, 1989; Spencer et al., 2001; Wernicke, 2011; Dominguez et al., 2012; Young, 2012; Young and Crow, 2014). This episode has been suggested as having been accompanied by large-scale normal faulting (Spencer and Reynolds, 1989) and unroofing (Flowers et al., 2008) along the southwestern part of the Colorado Plateau, and, potentially, a drainage reversal along the Mogollon Rim in Arizona (Dickinson, 1989; Wernicke, 2011). If such a faulting and drainage reversal occurred, it could have cut off the south-southwest Music Mountain Formation source of exotic arkosic gravels to the Hualapai paleocanyons, resulting in 
the local deposition of only finer sediments as the late Paleogene climate changed to a more arid regime.

Greenhouse conditions of the Early Paleogene (Fig. 12) started to deteriorate during the middle Eocene in the mid-continental region of the United States, as documented by changes in terrestrial flora and fauna (Retallack, 1992; Prothero, 1994). This deterioration led to increasingly arid conditions in the Late Eocene and then to the EOT. Note in Fig. 12 (lower inset) that "Antarctic Glaciation" indicates the abrupt increase in benthic $\delta^{18} \mathrm{O}$ values, which change marks the official Eocene/Oligocene boundary at 33.9 Ma and corresponds with the time of greatest cooling and aridification - climatic conditions that could fit well with the deposition of the fine-grained sediment of the West Water Formation and then its cementation by calcrete/dolocrete. Similarly, the abrupt decrease in $\delta^{18} \mathrm{O}$ values at around 26 million years labeled "Antarctic Thawing" (Fig. 12, lower inset) may signify the reinstitution of a wetter climate, coinciding with when Buck and Doe gravels began to be transported down the Hualapai paleocanyons.

The EOT is not only documented in the marine $\delta^{18} \mathrm{O}$ record (Fig. 12), but also by the terrestrial record of western North America. In the White River Group of Wyoming and Nebraska, late Eocene fluvial sedimentation was gradually replaced by eolian deposition across the EOT from about 34.6 to 32.7 Ma (Terry, 2001; Sahy et al., 2015). In addition, the Chuska Erg in the Four Corners region has an established EOT age (33.54 $\pm 0.25 \mathrm{Ma})$, as do the eolianites of the western Mogollon-Datil volcanic field $(33.51 \pm 0.14 \mathrm{Ma})$ midway along the Arizona-New Mexico border (Cather et al., 2008). The southwestern trend of known EOT deposits shown in Fig. 1 (upper inset) may suggest a possible regional change to a more arid climate beyond the badlands region and southwestward into New Mexico and Arizona. 


\section{CONCLUSIONS}

The aim of this study was to establish the mode of origin of the West Water Formation on the Hualapai Plateau, Colorado Plateau, Arizona, USA, using a variety of petrological, mineralogical and geochemical techniques. From these analyses we conclude the following:

- The bulk of the massive calcareous unit of the West Water Formation (the limestone unit of Young, 1966, 1999), as exposed in West Water and Milkweed canyons, consists predominantly of silt-sized quartz (and minor feldspar) grains within a structureless coalescing irregular to spherical pelloidal and nodular micritic carbonate cement. Patches of microspar cement are present throughout all sampled profiles, with greater proportions of microspar, and in some cases sparry calcite, cement towards the base of profiles. Samples from the uppermost part of the massive calcareous unit within Milkweed Canyon contain weakly developed pedogenic glaebular carbonate structures overprinting the pelloidal/nodular fabric. The upper-to-middle sections of the calcrete profiles are also dolomitized. SEM, XRD and TEM analyses confirm the presence of palygorskite within samples.

- Overlying and post-dating the massive calcareous unit is a "red-soil unit", consisting predominantly of silt-sized quartz grains within a matrix of palygorskite, Fe-Mg-rich smectite and minor Fe-oxide minerals.

- Sr-isotope analyses of samples of the red-soil unit and massive calcareous unit of the West Water Formation, plus samples of inter-gravel matrix from the stratigraphically older Music Mountain Formation and Hindu Fanglomerate, yield exceptionally high ${ }^{87} \mathrm{Sr} /{ }^{86} \mathrm{Sr}$ values of $\geq 0.719$. These most likely arise due to cementation from groundwaters passing through Music Mountain Formation arkosic sediments, which 
were derived from a high ${ }^{87} \mathrm{Sr} /{ }^{86} \mathrm{Sr}$ Precambrian source terrane to the south and southwest.

- On the basis of the preceding evidence, the West Water Formation limestone unit in West Water and Milkweed canyons is not a lacustrine limestone coeval with the lacustrine Long Point limestone on the Coconino Plateau. Instead, it is interpreted as a non-pedogenic valley calcrete - one of the thickest and best-exposed of its type in the world - capped by a 1-2m thick pedogenic calcrete, with upper-to-middle sections of the calcrete profile subsequently dolomitized to form a dolocrete. The overlying red-soil unit is a paleosol.

- Based on the overall evidence, we suggest that the calcrete-dolocrete and red-soil units of the West Water Formation record the Eocene-Oligocene Transition (EOT) in the Grand Canyon area that was contemporaneous with the EOT in the mid-continent White River Group "badlands," and with the EOT of the Chuska Erg and Mogollon-Datil eolianites along the Arizona-New Mexico border. We also suggest that the West Water Formation host sediment and cementing calcrete could have formed around the $E / O$ boundary at 33.9 Ma. Further chronological investigations are needed to confirm or refute this model.

Acknowledgements. The authors would like to thank the following: Owen Davis, for pollen analyses; John Geissman, for paleomagnetic information; Bob Buecher, Deb Buecher and Daniel Hill, for field assistance. Samples were analyzed by SEM at the UNM Radiogenic dating lab and University of Brighton imaging suite; EDS, TEM, XRD, and Sr-isotope geochemistry analyses were undertaken at UNM. Thin sections were made at the Open University, UK, and by Thomas Parkhill of Gold Hill Geological Research, USA. DJN's fieldwork costs were provided by the 
University of Brighton. Some of this research benefited from NSF grants EAR518601 and EAR0326902. Visitation to Milkweed Canyon, and the collection of samples therein, was by permit (\#31287) from the Hualapai tribe.

\section{REFERENCES}

Adamson, K., Candy, I., Whitfield, L., 2015. Coupled micromorphological and stable isotope analysis of Quaternary calcrete development. Quaternary Research 84, 272-286.

Alonso-Zarza, A.M., 2003. Palaeoenvironmental significance of palustrine carbonates and calcretes in the geological record. Earth-Science Reviews 60, 261-298.

Arakel, A.V., 1986. Evolution of calcrete in palaeodrainages of the Lake Napperby area, central Australia. Palaeogeography, Palaeoclimatology, Palaeoecology 54, 283-303.

Arakel, A.V., 1991. Evolution of Quaternary duricrusts in Karinga Creek drainage system, Central Australian groundwater discharge zone. Australian Journal of Earth Sciences 38, 333-347.

Arakel, A.V., McConchie, D., 1982. Classification and genesis of calcrete and gypsite lithofacies in palaeodrainage systems of inland Australia and their relationship to carnotite mineralization. Journal of Sedimentary Petrology 52, 1149-1170.

Arakel, A.V., Jacobson, G., Salehi, M., Hill, C.M., 1989. Silicification of calcrete in palaeodrainage basins of the Australian arid zone. Australian Journal of Earth Sciences 36, 73-89.

Billingsley, G.H., Wenrich, K.J., Huntoon, P.W., Young, R.A., 1999. Breccia-pipe and geologic map of the southwestern part of the Hualapai Indian Reservation and vicinity, Arizona. U.S Geological Survey, Miscellaneous Investigations Series Map I-2554, scale 1:48,000.

Buczynski, C., Chafetz, H.S., 2006. Siliclastic grain breakage and displacement due to carbonate crystal growth: an example from the Lueders Formation (Permian) of north-central Texas, USA: Sedimentology 34, 837-843. 
Butt, C.R.M., 1992. Semiarid and arid terrains. In: Butt, C.R.M., Zeegers, H. (Eds.), Regolith and Exploration Geochemistry in Tropical and Subtropical Terrains. Handbook of Exploration Geochemistry, Vol. 4. Elsevier, Amsterdam, pp. 295-391.

Carlisle, D., 1983. Concentration of uranium and vanadium in calcretes and gypcretes. In: Wilson, R.C.L. (Ed.), Residual Deposits: Surface Related Weathering Processes and Materials. Geological Society of London Special Publication, Vol. 11. Geological Society, London, pp. $185-195$.

Carlisle, D., Merifield, P.M., Orme, A.R., Kohl, M.S., Kolker, O., 1978. The distribution of calcretes and gypcretes in southwestern United States and their uranium favorability based on a study of deposits in Western Australia and South West Africa (Namibia). Open-file Report, GJBX-29 (78), subcontract 76-022-E, US Department of Energy, Grand Junction, CO.

Cather, S.M., Connell, S.D., Chamberlin, R.M., McIntosh, W.C., Jones, G.E., Potochnik, A.R., Lucas, S.G., Johnson, P.S., 2008. The Chuska erg: Paleogeomorphic and paleoclimatic implications of an Oligocene sand sea on the Colorado Plateau. Geological Society of America Bulletin 120, 13-33.

Coxall, H.K., Wilson, P.A., Palike, H., Lear, C.H., Backman, J., 2005. Rapid stepwise onset of Antarctic glaciation and deeper calcite compensation in the Pacific Ocean. Nature 433, 53-57. DeCelles, P.G., Kapp, P., Ding, L., Gehrels, G.E., 2007. Late Cretaceous to middle Tertiary basin evolution in the central Tibetan Plateau: Changing environments in response to tectonic partitioning, aridification, and regional elevation gain. Geological Society of America Bulletin $119,654-680$.

DeConto, R.M., Pollard, D., 2003. Rapid Cenozoic glaciation of Antarctica induced by declining atmospheric $\mathrm{CO}_{2}$. Nature 421, 245-249. 
Dickinson, W.R., 1989. Tectonic settings of Arizona through geologic time. In Jenney, J.P., Reynolds, S.J. (Eds.), Geologic evolution of Arizona. Arizona Geological Society Digest 17, 116.

Dominguez, L., Scharfschwerdt, P.R., Giorgis, S.D., Young, R.A., 2012. Abrupt 17-19 Ma Miocene volcanic episode along the Hualapai Plateau margin in western Arizona: Proxy for the onset of local Basin and Range extension (abs.). Geological Society of America, Abstracts with Programs, Rocky Mountain section, Albuquerque, p. 81.

Ferguson, C.A., McIntosh, W.C., Miller, C.F., 2013. Silver Creek caldera - the tectonically dismembered source of the Peach Spring Tuff. Geology 41, 3-6, doi:10.1130/G33551.1.

Flowers, R.M., Farley, K.A., 2012. Apatite ${ }^{4} \mathrm{He} /{ }^{3} \mathrm{He}$ and (U-Th)/He evidence for an ancient Grand Canyon. Science 338, 1616-1619.

Flowers, R.M., Wernicke, B.P., Farley, K.A., 2008. Unroofing, incision, and uplift history of the southwestern Colorado Plateau from apatite (U-Th)/He thermochronometry. Geological Society of America Bulletin 120, 571-587.

Goudie, A.S., 1983. Calcrete. In: Goudie, A.S., Pye, K. (Eds.), Chemical Sediments and Geomorphology. Academic Press, London, pp. 93-131.

Hay, R.L., Wiggins, B., 1980. Pellets, ooids, sepiolite and silica in three calcretes of the south western United States. Sedimentology 27, 559-576.

Hill, C.A., Polyak, V.J., Asmerom, Y., Provencio, P.P., 2016. Constraints on a Late Cretaceous uplift, denudation, and incision of the Grand Canyon region, southwestern Colorado Plateau, USA from U-Pb dating of lacustrine limestone. Tectonics 35, 896-906.

Huntington, K.W., Wernicke, B.P., Eiler, J.M., 2010. Influence of climate change and uplift of Colorado Plateau paleotemperatures from carbonate clumped isotope thermometry. Tectonics 29, TC3005, doi:10.1029/2009TC002449, 1-19. 
Huntington, K.W., Budd, D.A., Wernicke, B.P., Eiler, J.M., 2011. Use of clumped-isotope thermometry to constrain the crystallization temperature of diagenetic calcite. Journal of Sedimentary Research 81, 656-669.

Jacobson, G., Arakel, A.V., Chen, Y.J., 1988. The central Australian groundwater discharge zoneevolution of associated calcrete and gypcrete deposits. Australian Journal of Earth Sciences $35,549-565$.

Kaemmerer, M., Revel, J.C., 1991. Calcium carbonate accumulation in deep strata and calcrete in Quaternary alluvial formations of Morocco. Geoderma 48, 43-57.

Khadkikar, A.S., Merh, S.S., Malik, J.N., Chamyal, L.S., 1998. Calcretes in semi-arid alluvial systems: formative pathways and sinks. Sedimentary Geology 116, 259-260.

Khalaf, F.I., 2007. Occurrences and genesis of calcrete and dolocrete in the Mio-Pleistocene fluviatile sequence in Kuwait, northeast Arabian Peninsula. Sedimentary Geology 199, 129139.

Leier, A., Quade, J., DeCelles, P., Kapp, P., 2009. Stable isotopic results from paleosol carbonate in South Asia: Paleoenvironmental reconstructions and selective alteration. Earth and Planetary Science Letters 279, 242-254.

Lucchitta, I., Young, R.A., 1986. Structure and geomorphic character of Western Colorado Plateau in the Grand Canyon-Lake Mead region. In: Nations, D., Conway, C.M., Swann, G.A. (Eds.), Geology of central and northern Arizona. Geological Society of America; Rocky Mountain Section Guidebook, Flagstaff, AZ, pp. 159-176.

Machette, M.N., 1985. Calcic soils of the south-western United States. Geological Society of America Special Paper 203, pp. 1-21. 
Mack, G.H., Cole, D.R., Trevino, L., 2000.The distribution and discrimination of shallow, authigenic carbonates in the Pliocene-Pleistocene Palomas Basin, southern Rio Grande Rift. Geological Society of America Bulletin 112, 643-656.

Maizels, J., 1990a. Long-term palaeochannel evolution during episodic growth of an exhumed Plio-Pleistocene alluvial fan, Oman. In: Rachocki, A.H., Church, M. (Eds.), Alluvial Fans: a Field Approach. John Wiley, Chichester, pp. 271-304.

Maizels, J., 1990b. Raised channel systems as indicators of palaeohydrologic change: a case study from Oman. Palaeogeography, Palaeoclimatology, Palaeoecology 76, 241-277. Mann, A.W., Horwitz, R.C., 1979. Groundwater calcrete deposits in Australia. Some observations from Western Australia. Journal of the Geological Society of Australia 26, 293-303.

McFarlane, M.J., 1976. Laterite and Landscape. Academic Press, London.

McFarlane, M.J., 1983. Laterites. In: Goudie, A.S., Pye, K. (Eds), Chemical Sediments and Geomorphology. Academic Press, London, pp. 7-58.

McLaren, S.J., 1993. Use of cement types in the palaeoenvironmental interpretation of coastal aeolian sedimentary sequences. In: Pye, K. (Ed.), The Dynamics and Environmental Context of Aeolian Sedimentary Systems, Vol. 72. Geological Society of London Special Publication, London, pp. 235-244.

McLaren, S.J., 2004. Characteristics, evolution and distribution of Quaternary channel calcretes, southern Jordan. Earth Surface Processes and Landforms 29, 1487-1507.

Miller, R.P., 1937. Drainage lines in bas-relief. Journal of Geology 45, 432-438.

Nash, D.J., McLaren, S.J., 2003. Kalahari valley calcretes: their nature, origins, and environmental significance. Quaternary International 111, 3-22. 
Nash, D.J., Smith, R.F., 1998. Multiple calcrete profiles in the Tabernas Basin, southeast Spain: their origins and geomorphic implications. Earth Surface Processes and Landforms 23, 10091029.

Nash, D.J., Smith, R.F., 2003. Properties and development of channel calcretes in a mountain catchment, Tabernas Basin, southeast Spain: Geomorphology 50, 227-250.

Nash, D.J., Shaw, P.A., Thomas, D.S.G., 1994. Duricrust development and valley evolution: process-landform links in the Kalahari. Earth Surface Processes and Landforms 19, 299-317. Netterberg, F., 1969. The interpretation of some basic calcrete types. South African Archaeological Bulletin 24, 117-122.

Prothero, D.R., 1994. The Eocene-Oligocene Transition: Paradise Lost. In: Bottjer, D.J., Bambach, R.K. (Eds.), Critical Moments in Paleobiology and Earth History Series. Columbia University Press, New York, 291 pp.

Rakshit, P., Sundaram, R.M., 1998. Calcrete and gypsum crusts of the Thar Desert, Rajasthan, their geomorphic locales and use as palaeoclimatic indicators. Journal of the Geological Society of India 51, 249-255.

Reeves, C.C., 1983. Pliocene channel calcrete and suspenparallel drainage in West Texas and New Mexico. In: Wilson, R.C.L. (Ed.), Residual Deposits: Surface Related Weathering Processes and Materials. Geological Society of London Special Publication, Vol. 11. Geological Society, London, pp. 179-183.

Retallack, G.J., 1992. Paleosols and changes in climate across the Eocene/Oligocene boundary. In: Prothero, D.R., Berggnen, W.A. (Eds.), Eocene-Oligocene climate and biotic evolution. Princeton University Press, Princeton, NJ, pp. 382-398. 
Rodas, M., Luque, F. J., Mas, R., Garzoni, M.G., 1994. Calcretes, palycretes, and silcretes in the Paleogene detrital sediments of the Duero and Tajo basins, central Spain. Clay Minerals 29, 273-285.

Sahy, D., Condon, D.J., Terry, D.O., Fischer, A.U., Kuiper, K.F., 2015. Synchronizing terrestrial and marine records of environmental change across the Eocene-Oligocene transition. Earth and Planetary Science Letters 427, 171-182.

Singer, A., 1989. Palygorskite and sepiloite group minerals. In: Minerals in Soil Environment, Soil Science Society of America Book Series, Vol. 1, pp. 829-872.

Spencer, J.E.,Reynolds, S.J., 1989. Middle Tertiary tectonics of Arizona and adjacent areas. In: Jenny, J.P., Reynolds, S.J., Geologic evolution of Arizona. Arizona Geological Society Digest 17, 539-574.

Spencer, J.E., Richard, S.M., Ferguson, C.F., 2001. Cenozoic structure and evolution of the boundary between the Basin and Range and Transition Zone provinces in Arizona. In: Erskine, M.C., Faulds, J.E., Bartley, J.M., Rowley, P.D. (Eds.), The geologic transition, High Plateaus to Great Basin - A Symposium and Field Guide. Utah Geological Association Publication 30, 273289.

Talma, A.S., Netterberg, F., 1983. Stable isotope abundances in calcretes. In: Wilson, R.C.L. (Ed.), Residual Deposits: Surface Related Weathering Processes and Materials. Geological Society of London Special Publication, Vol. 11. Geological Society, London, pp. 221-233.

Tandon, S.K., Andrews, J.E., 2001. Lithofacies associations and stable isotopes of palustrine and calcrete carbonates: examples from an Indian Maastrichtian regolith. Sedimentology 48, 339355. 
Tandon, S.K., Narayan, D., 1981. Calcrete conglomerate, case-hardened conglomerate and cornstone: a comparative account of pedogenic and non-pedogenic carbonates from the continental Siwalik Group, Punjab, India. Sedimentology 28, 353-367.

Terry, D. O., 2001. Paleopedology of the Chadron Formation of Northwestern Nebraska: implications for paleoclimatic change in the North American midcontinent across the EoceneOligocene boundary: Palaeogeography, Palaeoclimatology, Palaeoecology 168, 1-38.

Verrecchia, E.P., Le Coustumer, M.N., 1996. Occurrence and genesis of palygorskite and associated clay minerals in a Pleistocene calcrete complex, Sde Boqer, Negev Desert, Israel. Clay Minerals 31, 183-202.

Watts, N.L., 1980. Quaternary pedogenic calcrete from the Kalahari (southern Africa): mineralogy, genesis and diagenesis. Sedimentology $27,661-686$.

Wernicke. B., 2011. The California River and its role in carving Grand Canyon. Geological Society of America Bulletin 123, 1288-1316.

Widdowson, M., 2007. Laterite and ferricrete. In: Nash, D.J., McLaren, S. (Eds), Terrestrial geochemical sediments and landscapes. John Wiley, Chichester, pp. 46-94.

Wright, V.P., 2007. Calcrete. In: Nash, D.J., McLaren, S. (Eds.), Terrestrial geochemical sediments and landscapes. John Wiley, Chichester, pp. 10-45.

Wright, V.P., Tucker, M.E., 1991. Calcretes: an Introduction. In: Wright, V.P., Tucker, M.E. (Eds.) Calcretes. Reprint Series 2. International Association of Sedimentologists, Blackwell, Oxford pp. 1-22.

Yaalon, D.H., 1997. Red Mediterranean soils: What make them different? Catena 18, 157-169.

Young, R.A., 1966. Cenozoic geology along the edge of the Colorado Plateau in northwestern Arizona: PhD thesis, Washington University, St. Louis, MO, USA. 167 pp. 
Young, R.A., 1979. Laramide deformation, erosion and plutonism along the southwestern margin of the Colorado Plateau. Tectonophysics 61, 25-47.

Young, R.A., 1982. Paleomorphic evidence for the structural history of the Colorado Plateau margin in western Arizona. In: Frost, E.G., Martin, D.L. (Eds.), Mesozoic-Cenozoic tectonic evolution of the Colorado River region, California, Arizona, and Nevada. Cordilleran, San Diego, pp. 29-39.

Young, R.A., 1999. Nomenclature and ages of Late Cretaceous(?)-Tertiary strata in the Hualapai Plateau Region, Northwest Arizona. Appendix in: Billingsley, G.H., Wenrich, K.J., Huntoon, P.W., Young, R.A., Breccia-pipe and geologic map of the Southwestern part of the Hualapai Indian Reservation and Vicinity, Arizona. U.S. Geological Survey Miscellaneous Investigations Series Map I-2554, pp. 21-50.

Young, R.A., 2001a. Geomorphic, structural, and stratigraphic evidence for Laramide uplift of the southwestern Colorado Plateau margin in northwestern Arizona. In: Ersking, M.C., Faulds, J.E., Bartley, J.M., Rowley, P.D., The geologic transition, high plateaus to Great Basin - a symposium and field guide. The Mackin volume, Utah Geological Association, pp. 227-237.

Young, R.A., 2001b. The Laramide-Paleogene history of the western Grand Canyon region: Setting the stage, In: Young, R.A., Spamer, E.E. (Eds.), The Colorado River: Origin and evolution. Grand Canyon Association Monograph 12, Grand Canyon, Ch. 1, pp. 7-15. Young, R.A., 2007. The post-Laramide disconformity in northwest Arizona: a proxy for the Eocene-Oligocene transition. GSA Abstracts with Programs 39, 44.

Young, R.A., 2011. Brief geologic history of the Peach Springs Quadrangle and the Hualapai Plateau, Mohave County, Arizona (Hualapai Indian Reservation). Arizona Geological Survey, Contributed Report CR-11-0, 28 pp. 
Young, R.A., 2012. Paleogene emergence of the southwestern margin of the Colorado Plateau as a topographic barrier: Evidence for pre-Basin and Range, Late Eocene (?)-Early Oligocene tectonism (abs.). Geological Society of America Abstracts with Programs 44, Rocky Mountain section, Albuquerque, 80 .

Young, R.A., Crow, R., 2014. Paleogene Grand Canyon incompatible with Tertiary paleogeography and stratigraphy. Geosphere 10, 664-679.

Young, R.A., Hartman, J.H., 2014. Paleogene rim gravel of Arizona: Age and significance of the Music Mountain Formation. Geosphere 10, 870-891.

Young, R.A., McKee, E.H., 1978. Early and middle Cenozoic drainage and erosion in west-central Arizona. Geological Society of America Bulletin 89, 1745-1750.

Young, RA., Crow, R., Peters, L., 2011. Oligocene tuff supports older Paleocene-Eocene age of Hualapai Plateau basal Tertiary section. In: Beard, L.S., Karlstrom, K.E., Young, R.A., Billingsley, G.H., U. S. Geological Survey Open File Report 2011-1210, 267-273.

Zachos, J., Pagani, M., Sloan, L., Thomas, E., Billups, K., 2001. Trends, rhythms, and aberrations in global climate 65 Ma to present. Science 292, 686-693. 


\section{FIGURES}

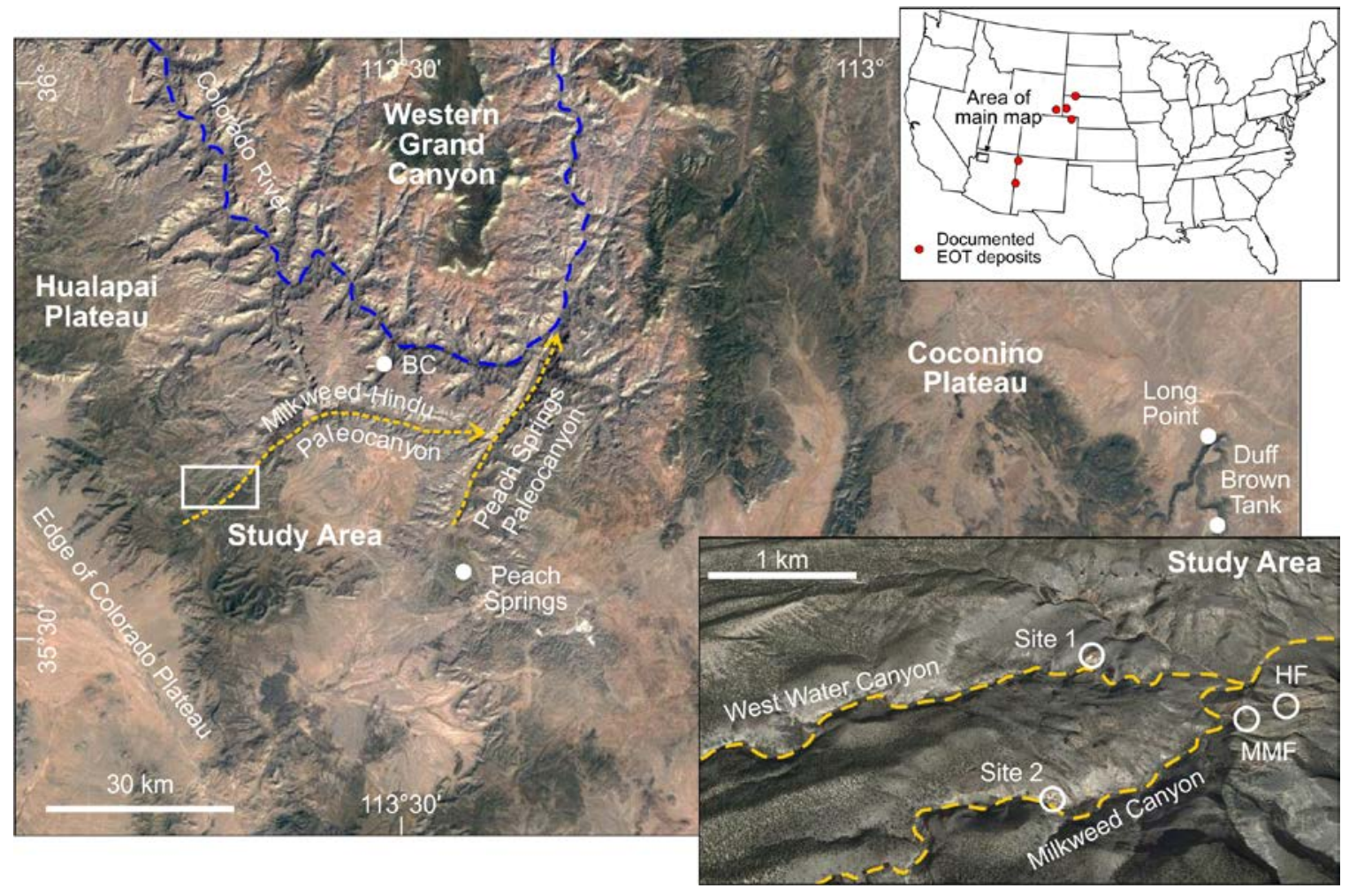

Figure 1. The Hualapai and Coconino Plateau areas of the western Grand Canyon region, Arizona, USA, and places mentioned in the text. BC in main figure = Bridge Canyon. Lower inset: close-up of the study area and the two collection sites in Milkweed and West Water canyons; also collection sites of the Music Mountain Formation (MMF) and Hindu Fanglomerate samples for ${ }^{87} \mathrm{Sr} /{ }^{86} \mathrm{Sr}$ and thin-section analyses. Upper inset: location of documented Eocene-Oligocene Transition (EOT) deposits in relation to the western plateaus on the main figure. Main figure and lower insert courtesy of Google Earth. 


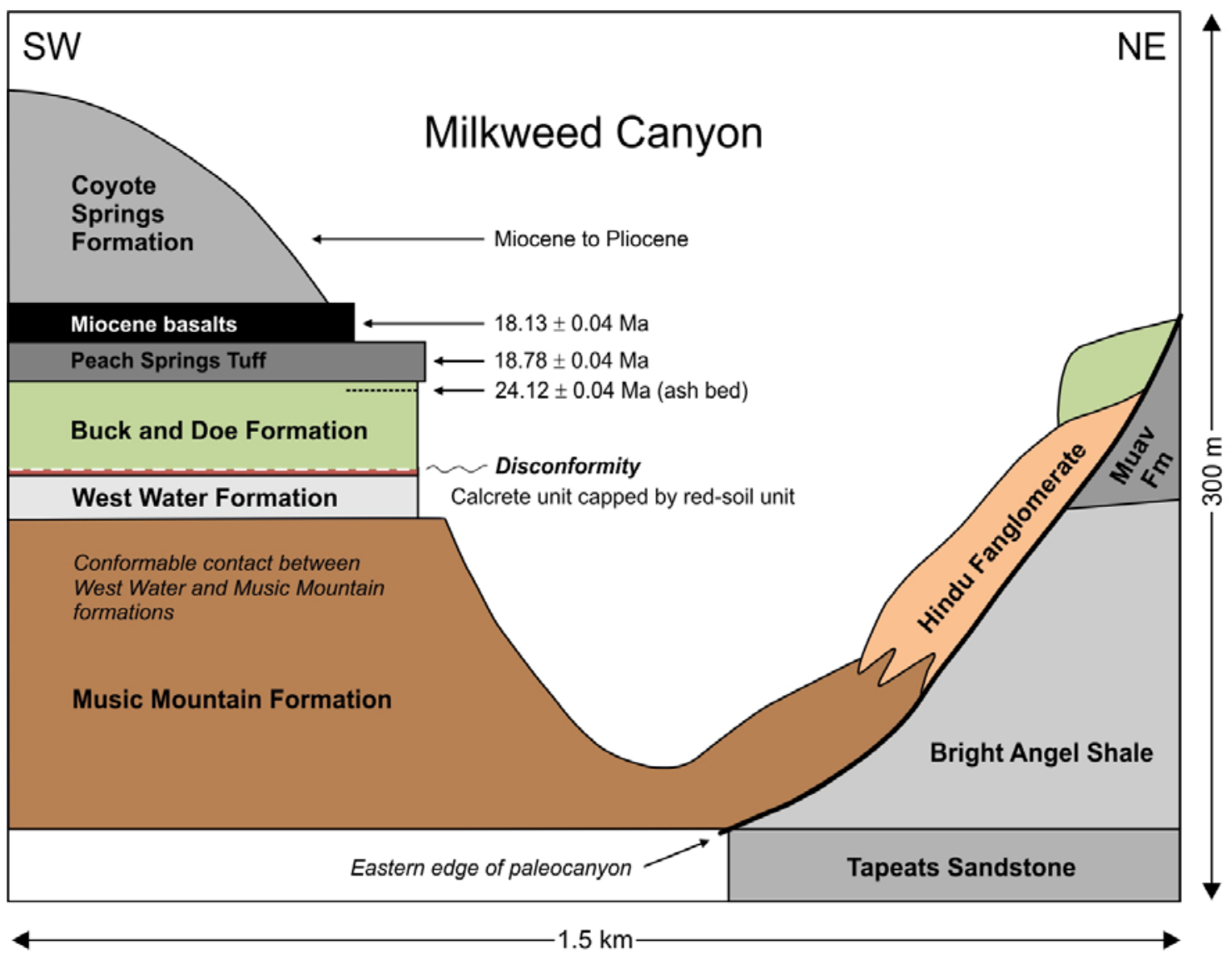

Figure 2. Schematic cross-section of Milkweed Canyon, the type section for the West Water Formation (WWF), including established ages for some of the strata above the West Water Formation. Age of one of the Miocene basalts overlying the Peach Springs Tuff from Young and Hartman (2014); Peach Springs Tuff from Ferguson et al. (2013); ash bed within Buck and Doe Formation from Young and Hartman (2014). 


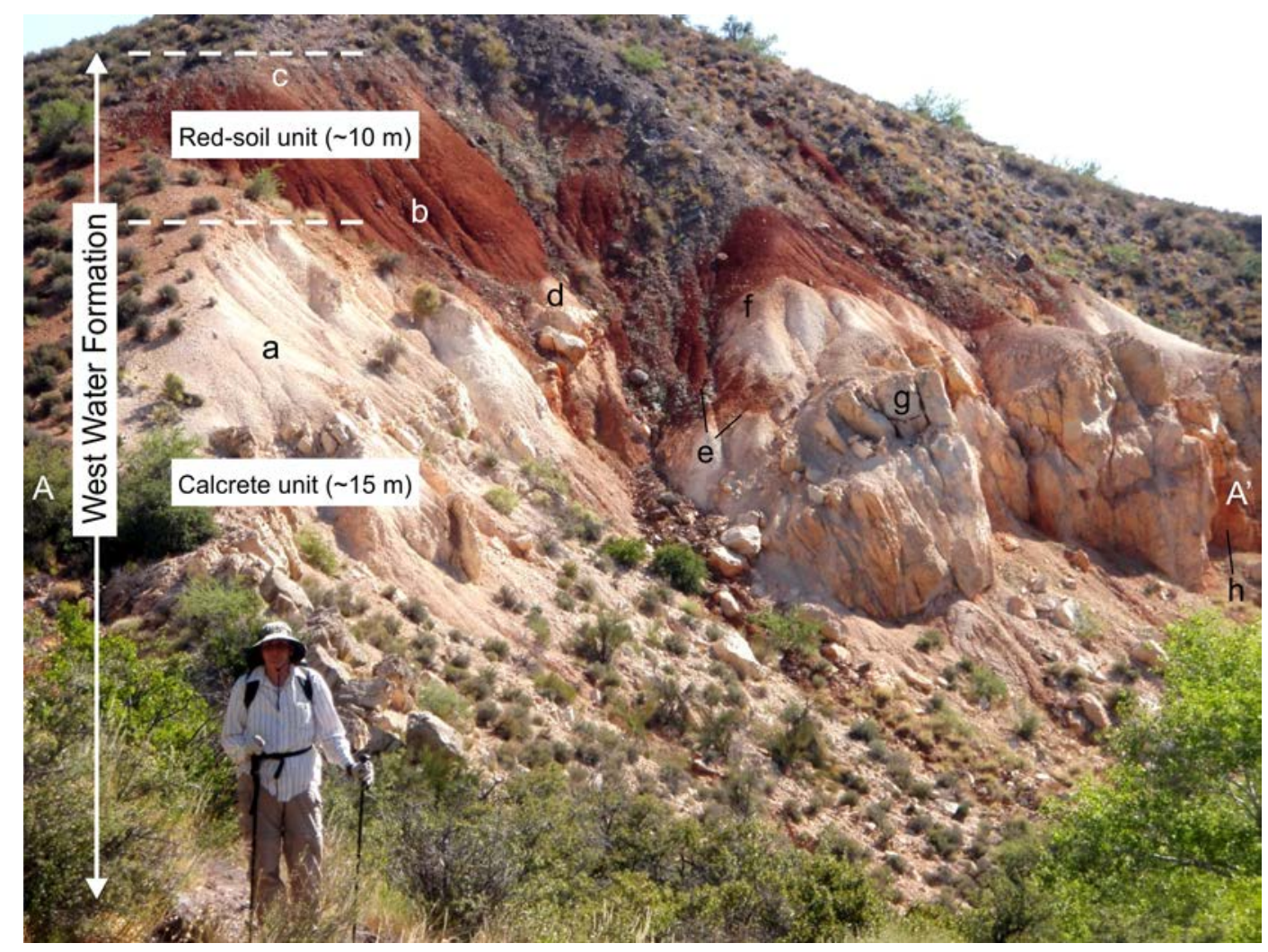

Figure 3. The West Water Formation (WWF) sample profile (A-A') in West Water Canyon (site 1, Fig. 1. lower inset), looking north-northeast. (a) Massive calcareous unit of the West Water Formation, which is predominantly a valley calcrete but is dolomitized in places. Note the broad lens-shape of the outcrop, which is typical of calcrete pods within valley calcretes elsewhere (see text for discussion). Note also that these units dip to the west, suggesting slumping. (b) The red-soil unit of the West Water Formation. (c) Contact between the top of the red-soil unit and the overlying Buck and Doe Formation; the thickness of the red-soil unit is about $10 \mathrm{~m}$ in this section, but is variable across the outcrop. (d) Contact between the massive calcareous unit and red-soil unit. This looks sharp but may be partly erosional. (e) Note how the red soil has been brought down the small gully by erosion to partly cover the massive calcareous unit (left arrow), and also how weathering of the massive calcareous unit (possibly as a result of water flushing down the gully) has left behind pockets of residual red soil along the sides of the gully (e.g. right arrow). (f) Note also how just below the contact between the two units the color of the massive calcareous unit changes gradually upwards, from white to light pink to darker reddish brown. This could be the result of staining or the partial dissolution of the upper surface of the calcareous unit. (g) This section of the massive calcareous unit is cemented by dolomite, with high-Mg calcite in the uppermost part of the profile (near f). (h) The basal unit of the West Water Formation contains the highest sand content, and may represent the very top of the transition zone between the Music Mountain Formation (MMF) and the base of the West Water Formation. Photo by Bob Buecher. 


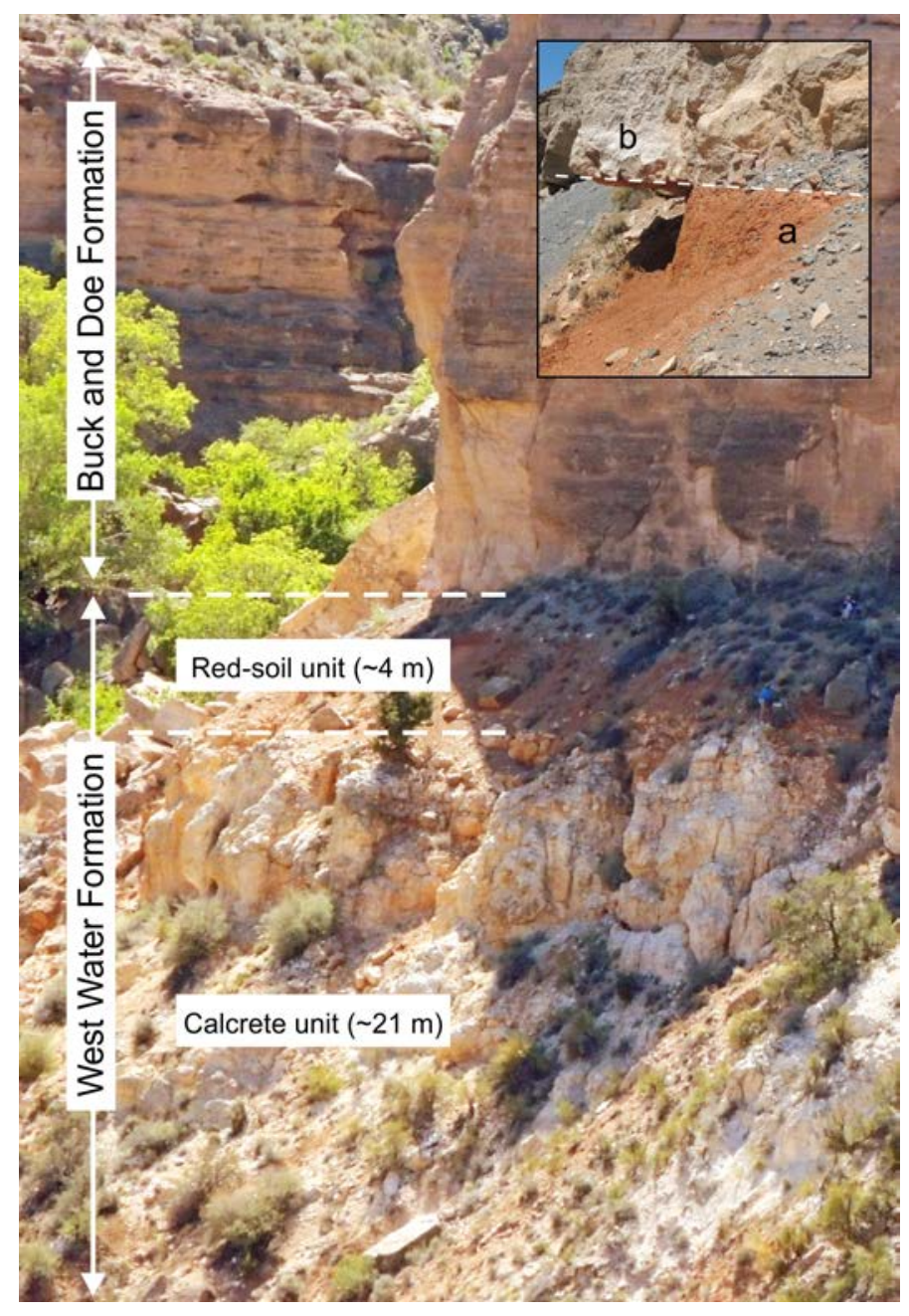

Figure 4. The West Water Formation (WWF) at its type section, Milkweed Canyon (site 2, Fig. 1. lower inset), looking west-southwest. The cliff face immediately below the contact between the massive calcareous (calcrete) unit and red-soil unit has been dolomitized to form a dolocrete (see sample WWLS-MW6, Table 2), with calcite cement in the remainder of the profile. Two profiles were sampled through the section here. Note the people on the right of the red-soil unit for scale. Upper inset: Close-up of the sharp boundary between the red-soil unit of the West Water Formation (a) and the overlying Buck and Doe Formation (b). 

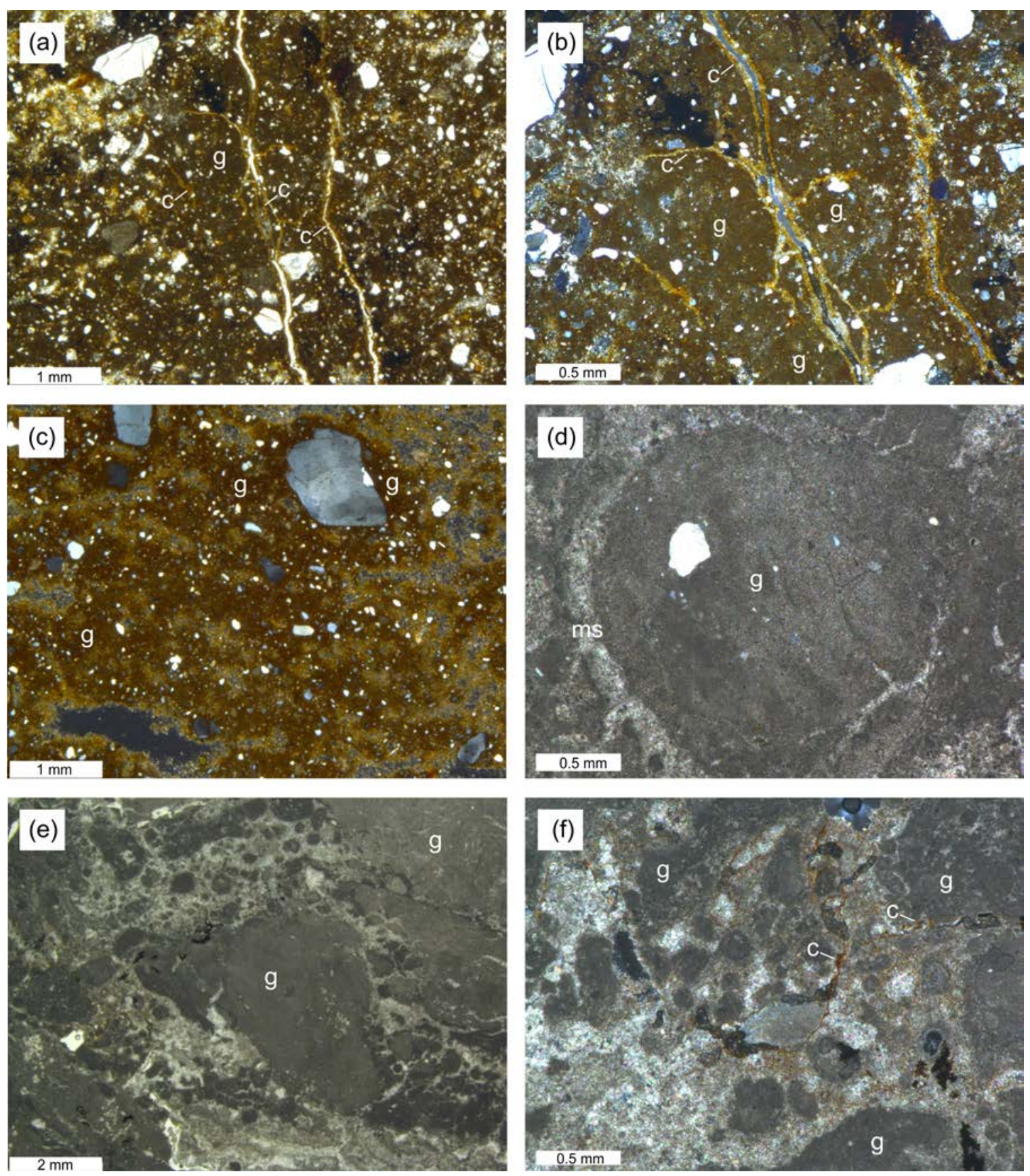

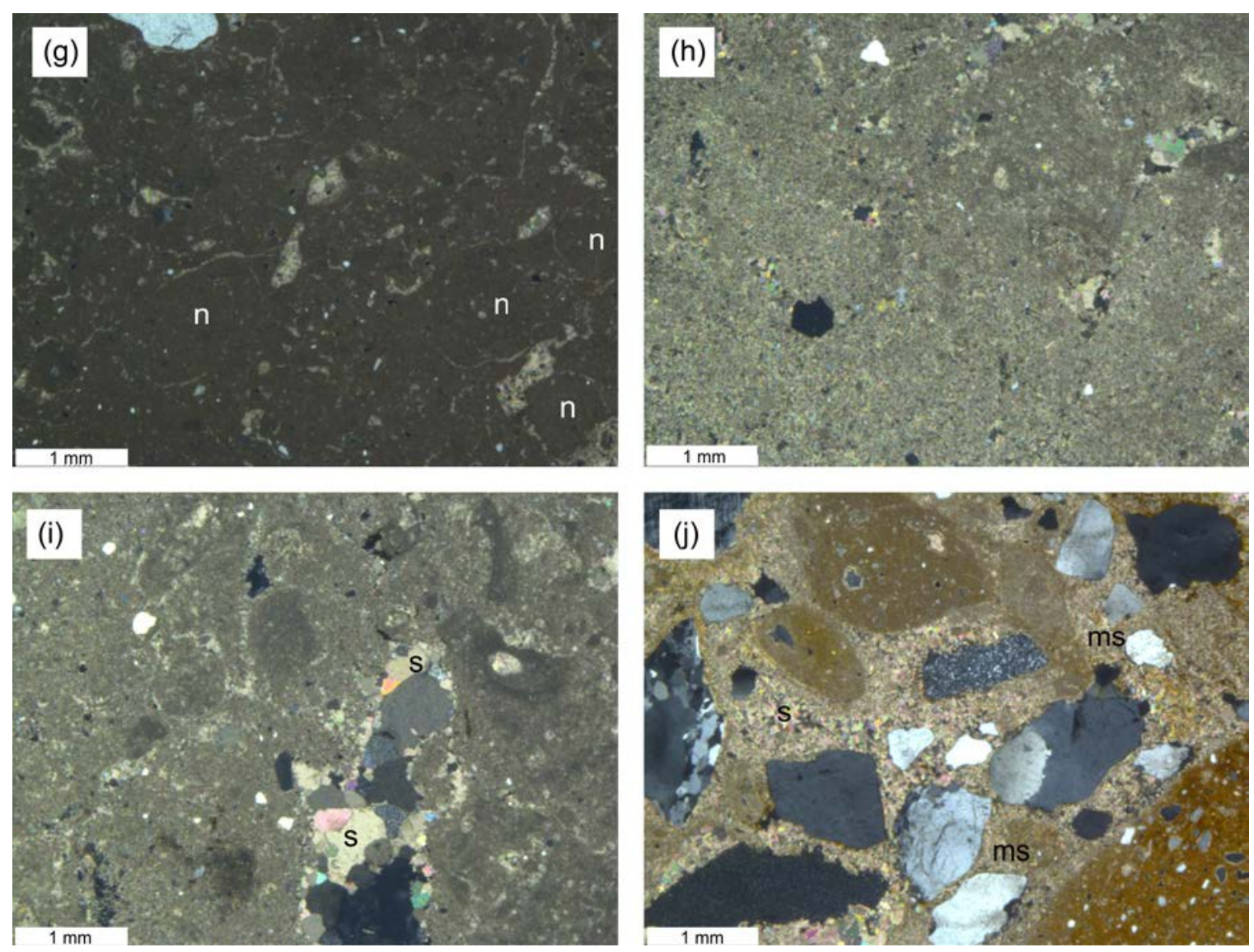

Figure 5. Thin-section photomicrographs from the red-soil unit (a-c) and massive calcareous unit (d-j), Milkweed Canyon profile 2. Photomicrographs (a) (plane-polarized light; ppl), (b) and (c) (both cross-polarized light; $x p l)$ illustrate the strong reddening within the red-soil unit, and the abundance of darker glaebular structures (labelled g), micro-aggregates of clay minerals, and cutans (labelled c) lining some void spaces (notably in the sub-vertical cracks running through (a) and (b)). Photomicrographs (d) (xpl) and (e) (ppl) illustrate typical pedogenic glaebular structures (labelled g) present at the very top of the massive calcareous unit; these appear to be superimposed onto a non-pedogenic nodular micrite-dominated fabric. Note the microspar rim cement (labelled ms) surrounding the pedogenic glaebule in (d). Photomicrograph (f) (xpl) from an oriented sample illustrates how gravitational clay linings (labelled $\mathrm{c}$ ) occur in the base of some sub-horizontal fractures. Photomicrograph (g) (xpl), depth $\sim 9 \mathrm{~m}$ within the massive calcareous unit, illustrates the coalescing nodular (labelled $n$ ) micrite-dominated fabric present throughout middle sections of the unit, with only minor patches of late-stage microspar and sparry calcite cement present. In other parts of the same sample (photomicrograph $\mathrm{h} ; \mathrm{xpl}$ ), a massive, structureless, micrite-dominated cement is present. Photomicrographs (i) and (j) (both $\mathrm{xpl}$ ), from depths of $\sim 12$ and $\sim 18 \mathrm{~m}$, respectively, illustrate the increasing abundance of latestage microspar (labelled $\mathrm{ms}$ ) and sparry calcite (labelled $\mathrm{s}$ ) cements present towards the base of the massive calcareous unit. Photomicrograph (j) also illustrates the increase of quartz grains in basal calcrete samples. 

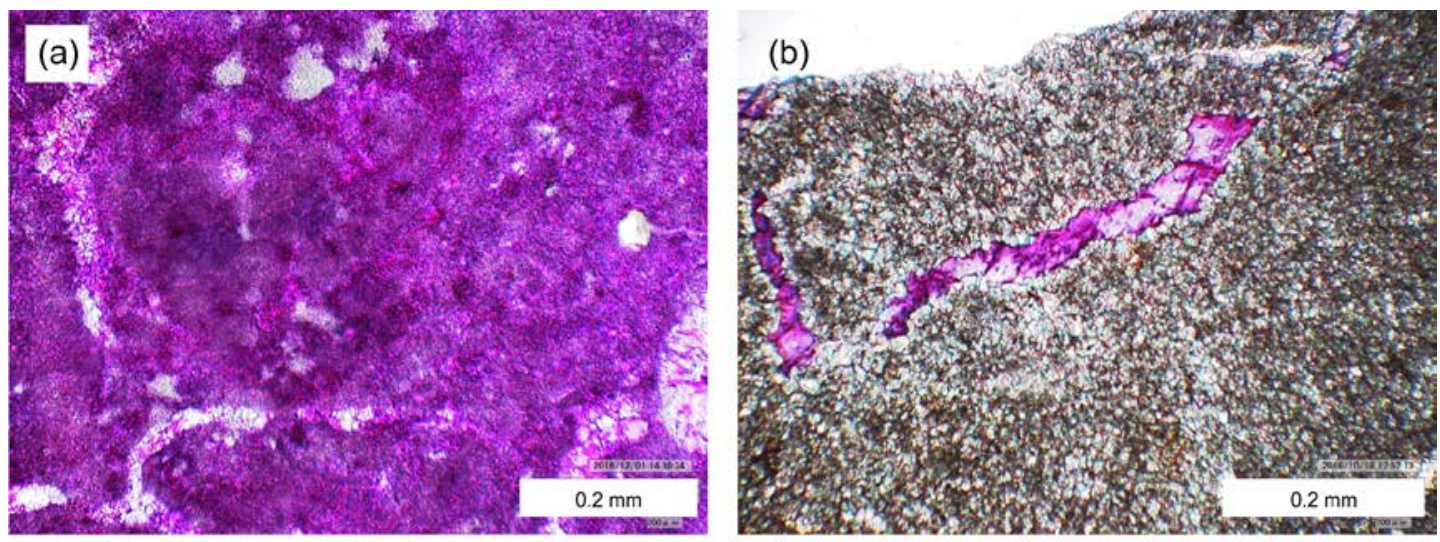

(c)

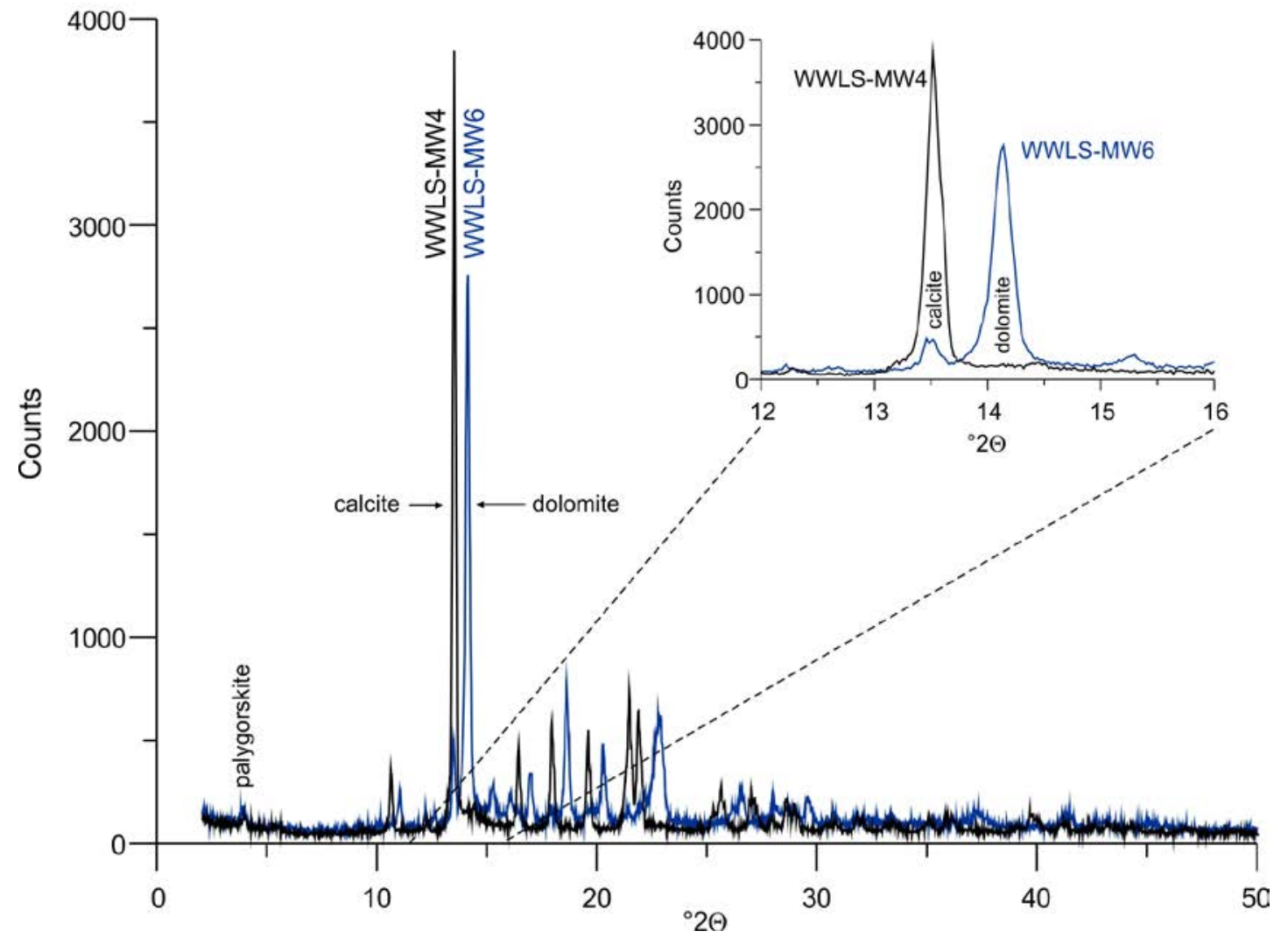

Figure 6. Thin sections of (a) calcrete from Milkweed Canyon profile 1 (sample WWLS-MW4) and (b) dolocrete from West Water Canyon (sample WWLS-WW3) stained with Alizarin Red. (c) XRD analyses of whole rock powders, which indicate that samples from the middle of Milkweed Canyon profile 1 (e.g. WWLS-MW4, see also Table 2) consist predominantly of calcite, and those from the top of the same profile (WWLS-MW6, see also Table 2 and Fig. 4) consist predominantly of dolomite with minor calcite. XRD analysis used molybdenum radiation with a wavelength of $0.7093 \AA$. Overall, the XRD and ICP-MS results suggest (i) the dominance of calcite cements in the majority of sampled profiles, and (ii) the presence of dolomite (with calcite void fills) in upper-to-middle parts of profiles. 

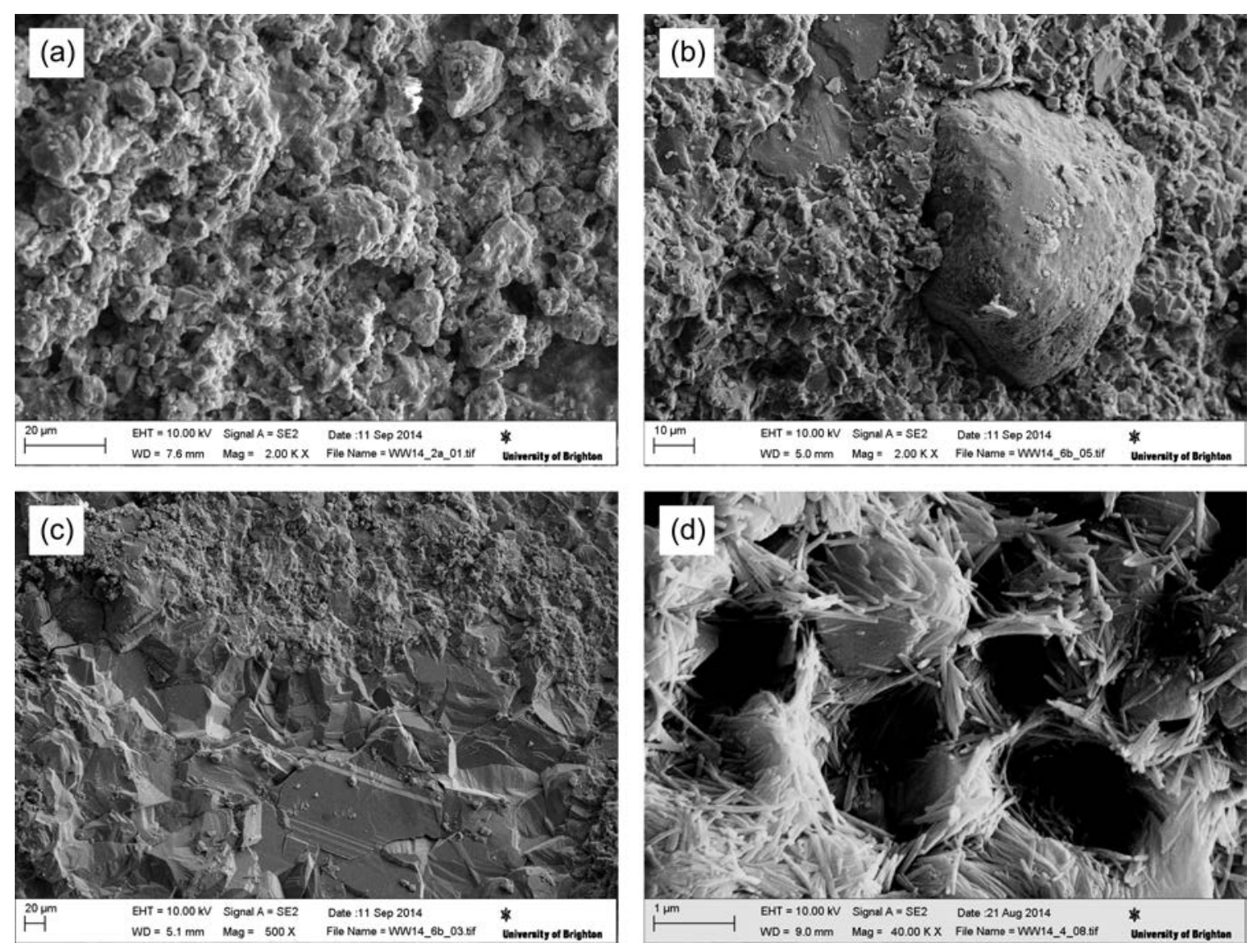

Figure 7. Scanning electron micrographs of calcrete samples from Milkweed Canyon profile 2. These illustrate (a) the typical micritic calcite cement and (b) silt/sand-sized quartz particles present throughout the valley calcrete component of the profile. Cracks and voids within the micrite matrix filled with (c) microspar and sparry calcite or (d) coated with palygorskite crystals are also common, with the proportion of sparry calcite increasing with depth. 

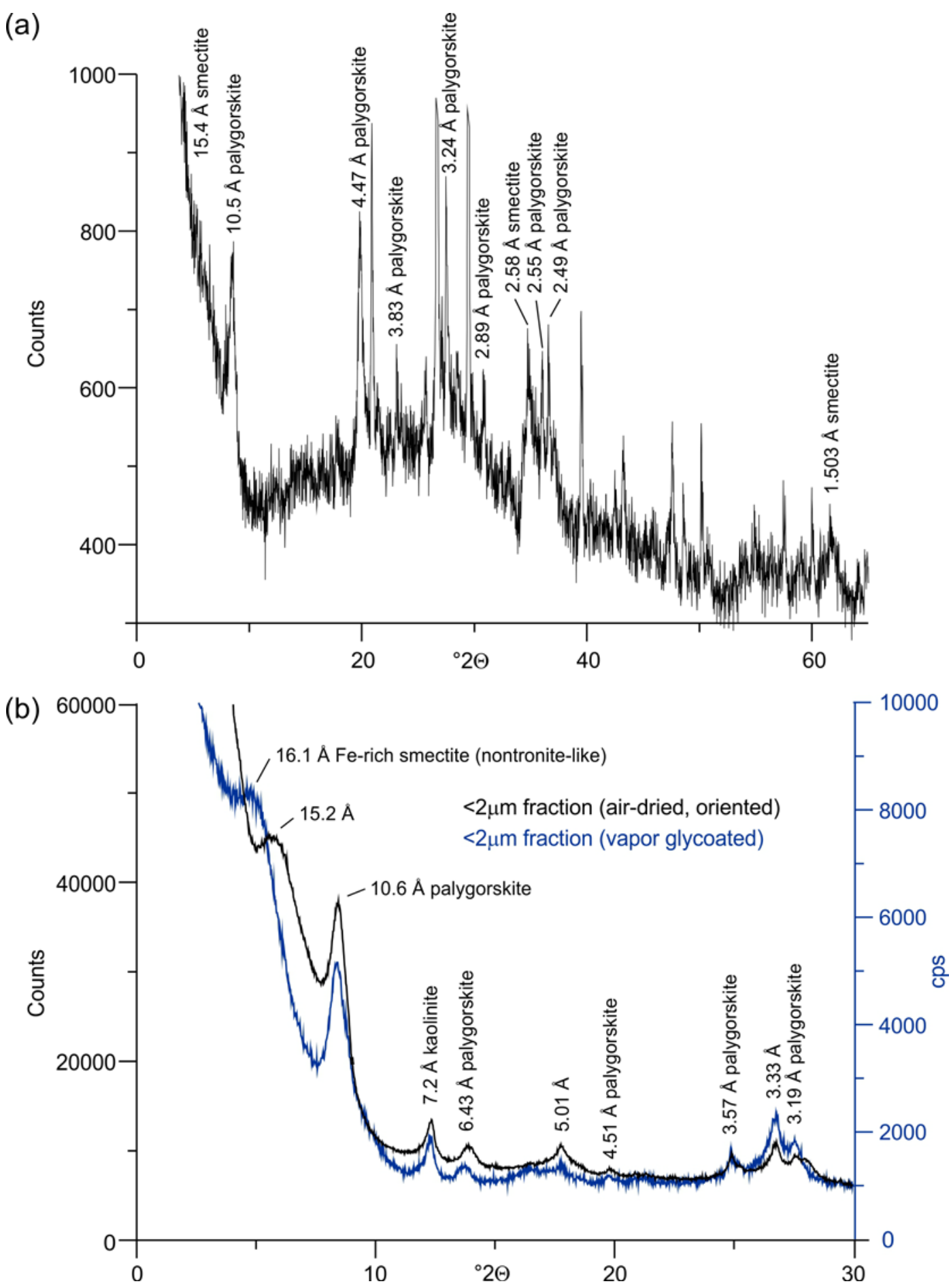

Figure 8. (a) Powder diffraction pattern for a 10- $\mu \mathrm{m}$ separate of red-soil unit, showing multiple characteristic palygorskite peaks. Separate consists mainly of smectite and palygorskite. (b) Oriented diffraction pattern for a 2- $\mu \mathrm{m}$ separate of red-soil unit, showing palygorskite and FeMg-rich smectite. XRD analyses for both (a) and (b) used copper radiation with a wavelength of $1.54059 \AA$ A. 

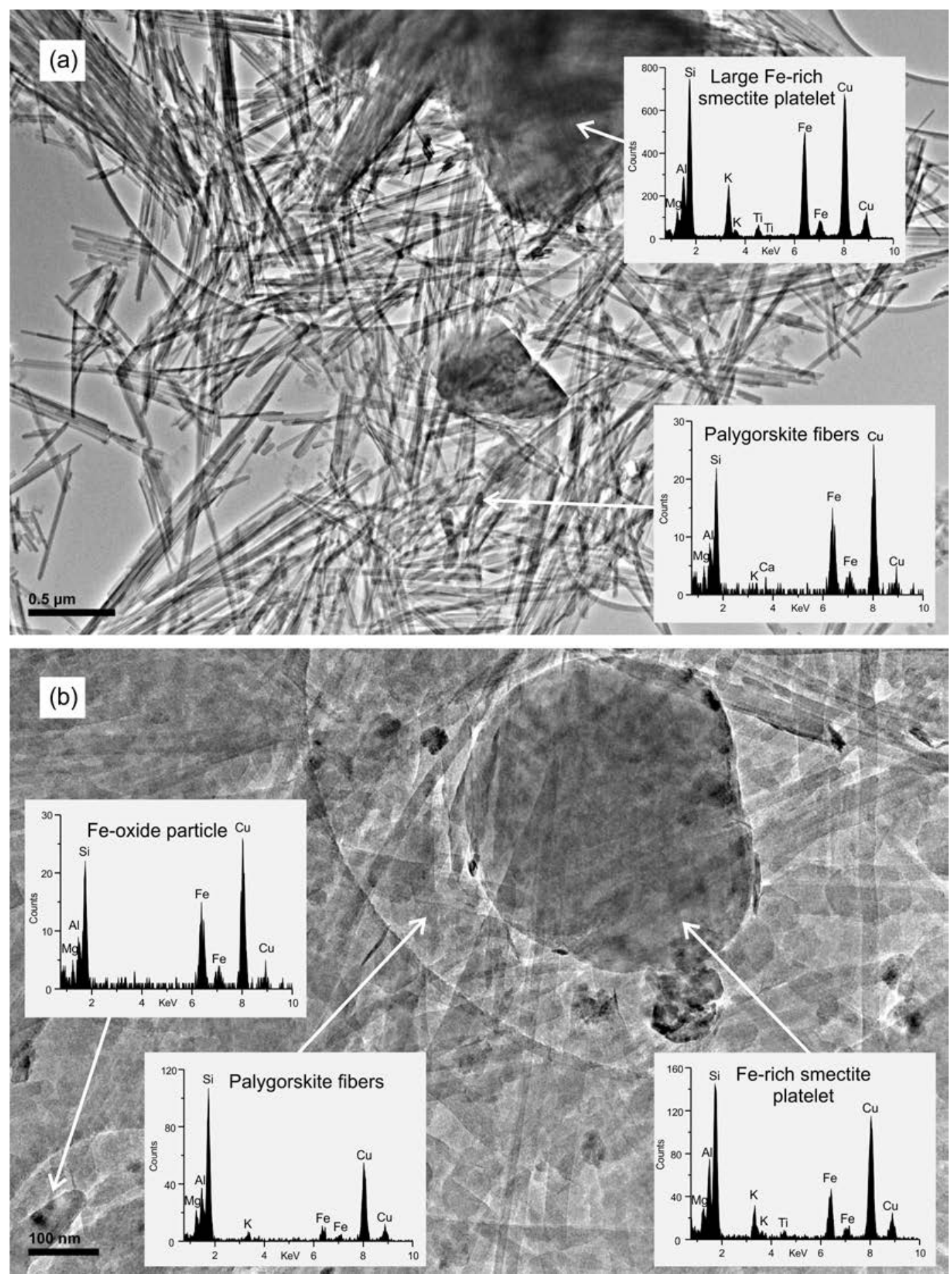

Figure 9. Transmission electron microscopy of (a) the clay fraction of the red-soil unit, and (b) the insoluble residue of the valley calcrete component of the Milkweed Canyon profile (sample WWLS-MW3). Both the red-soil unit and valley calcrete insoluble residue contain abundant palygorskite and smectite. Energy dispersive spectroscopy shows abundant Fe in both the smectite and palygorskite fibers. 


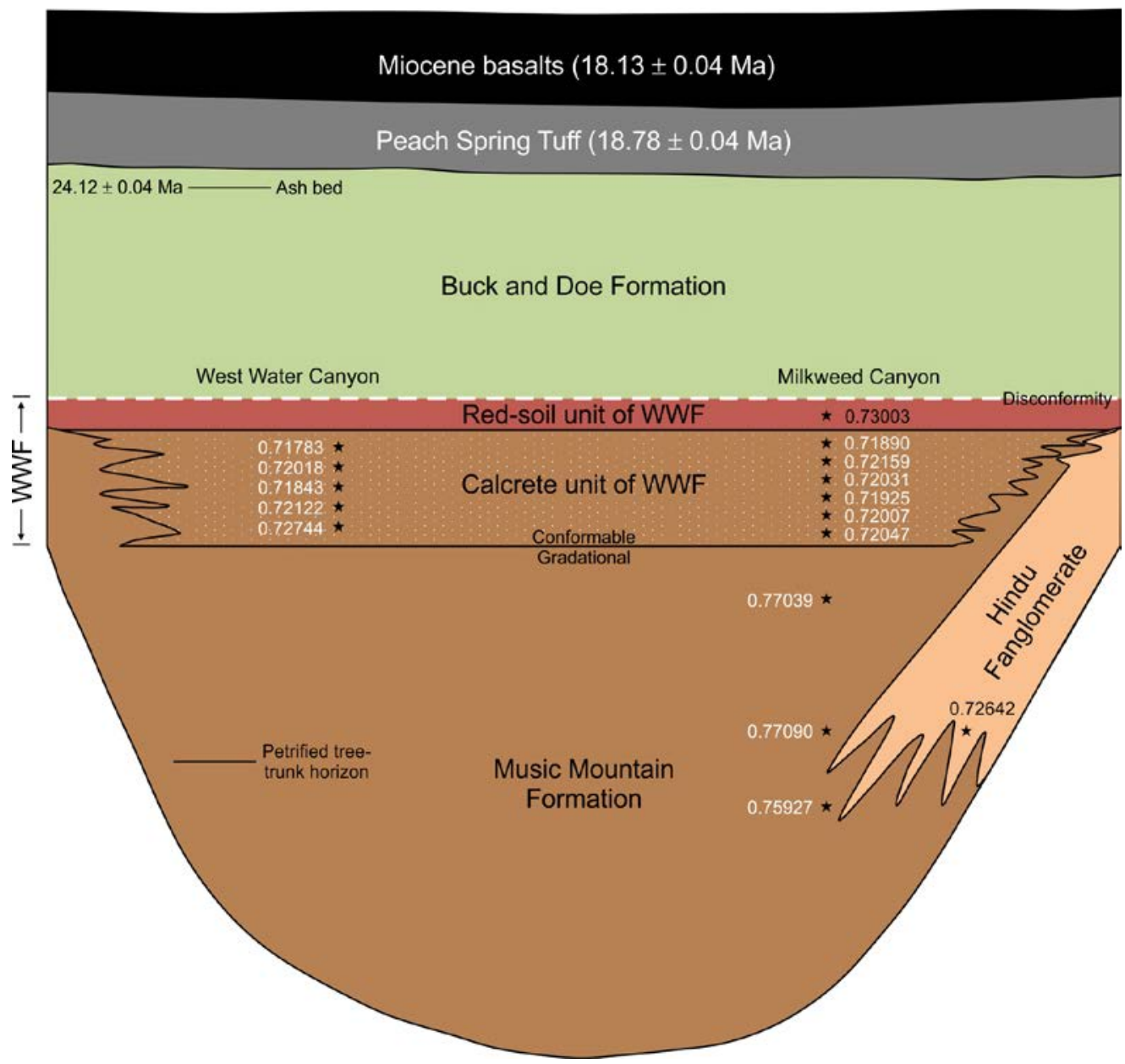

Figure 10. Schematic diagram showing ${ }^{87} \mathrm{Sr} /{ }^{86} \mathrm{Sr}$ values and $\mathrm{U}-\mathrm{Pb}$ ages for the various stratigraphic units in Milkweed and West Water Canyons, Hualapai Plateau. Age of Miocene basalts from Young and Hartman (2014); Peach Springs Tuff from Ferguson et al. (2013); ash bed within Buck and Doe Formation from Young and Hartman (2014). 


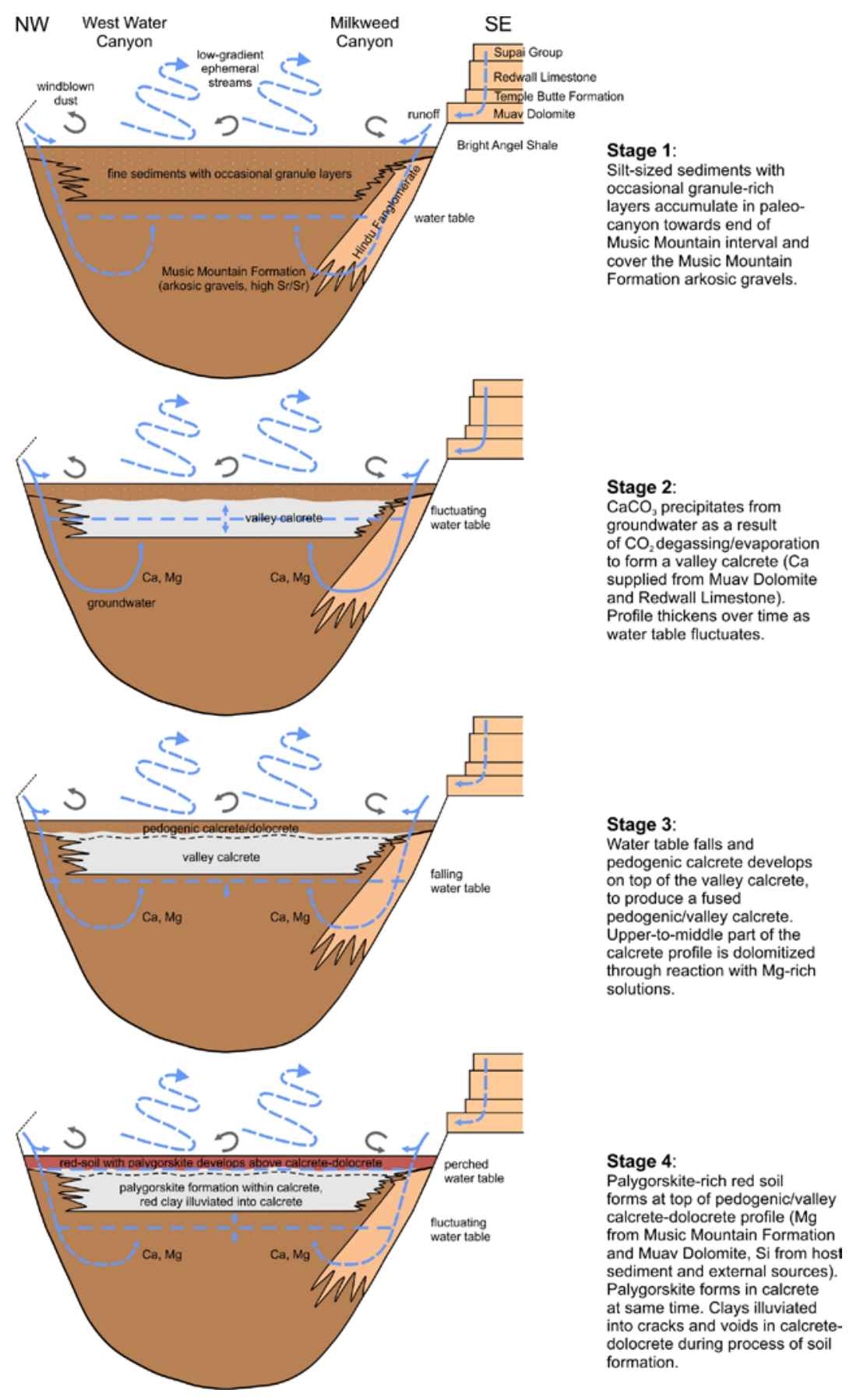

Figure 11. A four-stage model for the development of the West Water Formation calcretedolocrete and paleosol sequence within paleocanyons of the Hualapai Plateau. Stage 1: deposition of fine-grained sediments within a paleocanyon. Stage 2: precipitation of valley calcrete at or near the water table to cement the fine-grained sediments. Stage 3: the development of a pedogenic calcrete on top of the valley calcrete, with dolomitization of the uppermost section of the pedogenic-valley calcrete profile. Stage 4: development of the palygorskite-rich red-soil unit, with lesser palygorskite neoformation within the underlying calcrete-dolocrete. 


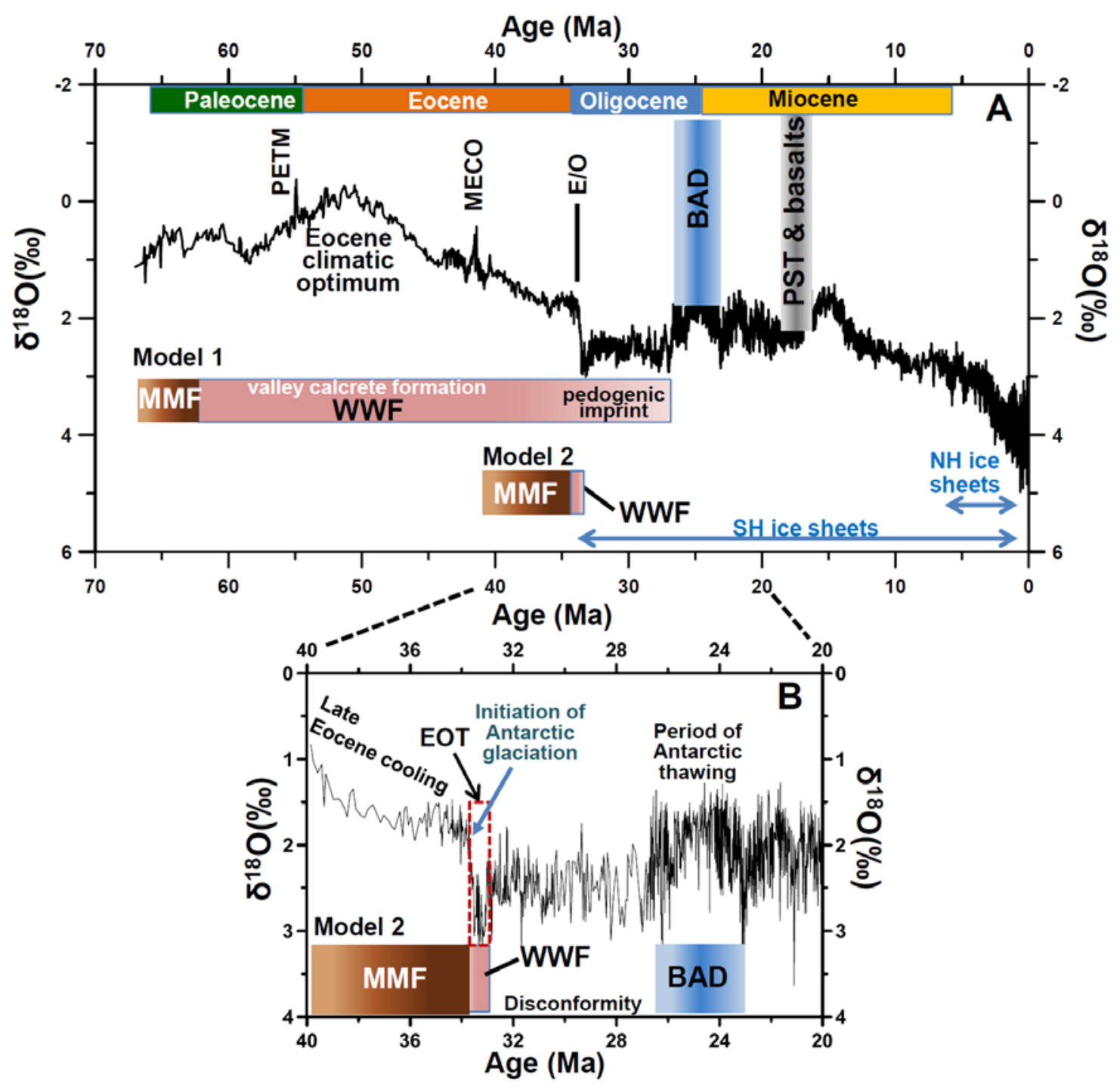

Figure 12. Two models for the age of the West Water Formation (WWF) relative to global paleoclimate, based on investigations of deep sea sediment cores (Zachos et al., 2001). Upper graph, Model \#1, where the West Water Formation valley calcrete formation took a very long time ( $~ \leq 36$ Ma duration), from the Paleocene onward to the deposition of the Buck and Doe Formation (BAD). Note that the relative timing of Model \#2 is also shown in this graph for comparison. Lower graph, Model \#2, where the West Water Formation formed during the initiation of the first Southern Hemisphere (SH) glaciations around the Eocene-Oligocene Transition (EOT) from 34-33 Ma (or over 1 Ma duration). According to Model \#2, the disconformity between the West Water Formation and Buck and Doe Formation would have been about 7-8 Ma duration. PETM = Paleocene-Eocene Thermal Maximum; $\mathrm{MECO}=$ Middle Eocene Climatic Optimum; E/O = Eocene/Oligocene boundary; MMF = Music Mountain Formation; NH = Northern Hemisphere; PST = Peach Springs Tuffs. 
Table 1. Details of methods applied to individual samples.

\begin{tabular}{|c|c|c|c|}
\hline Location & Unit & $\begin{array}{l}\text { No. } \\
\text { samples }\end{array}$ & Methods \\
\hline West Water Canyon & $\begin{array}{l}\text { Massive calcareous } \\
\text { unit }\end{array}$ & 5 & $\begin{array}{l}\text { Petrographic thin-section (one per sample), stable C- and O- } \\
\text { isotope geochemistry, Sr-isotope geochemistry, XRD, ICP- } \\
\text { MS, pollen analysis }\end{array}$ \\
\hline Milkweed Canyon Profile 1 & Red-soil unit & 1 & EDS, TEM, XRD, Sr-isotope geochemistry \\
\hline Milkweed Canyon Profile 1 & $\begin{array}{l}\text { Massive calcareous } \\
\text { unit }\end{array}$ & 6 & $\begin{array}{l}\text { Petrographic thin-section (one per sample), Sr-isotope } \\
\text { geochemistry, EDS, XRD, ICP-MS }\end{array}$ \\
\hline Milkweed Canyon Profile 2 & Red-soil unit & 1 & Petrographic thin-section (two per sample) \\
\hline Milkweed Canyon Profile 2 & $\begin{array}{l}\text { Massive calcareous } \\
\text { unit }\end{array}$ & 8 & $\begin{array}{l}\text { Petrographic thin-section (two per sample), SEM (three chips } \\
\text { per sample) }\end{array}$ \\
\hline Milkweed Canyon & $\begin{array}{l}\text { Hindu } \\
\text { Fanglomerate }\end{array}$ & 1 & Petrographic thin-section, Sr-isotope geochemistry \\
\hline
\end{tabular}


Table 2. Elemental data for samples from the massive calcareous unit in Milkweed and West Water canyons. Analysis by ICP-MS.

\begin{tabular}{|l|l|r|r|r|r|r|}
\hline Location & Sample & $\begin{array}{l}\text { Approximate } \\
\text { depth }(\mathbf{m})\end{array}$ & \multicolumn{1}{l}{ Mg (\%) } & \multicolumn{1}{l|}{ Sr (ppm) } & \multicolumn{1}{l}{ Ba (ppm) } & Ca (\%) \\
\hline Milkweed Canyon Profile 1 & WWLS-MW6 & \multicolumn{1}{|c|}{3} & $11.8 \pm 0.7$ & $251.2 \pm 1.0$ & $63.0 \pm 1.7$ & $25.6 \pm 1.3$ \\
\hline Milkweed Canyon Profile 1 & WWLS-MW5 & 4.3 & $0.3 \pm 0.9$ & $6.6 \pm 1.0$ & $19.8 \pm 1.7$ & $35.9 \pm 1.2$ \\
\hline Milkweed Canyon Profile 1 & WWLS-MW4 & 5.5 & $0.3 \pm 1.3$ & $5.3 \pm 0.4$ & $8.6 \pm 0.9$ & $35.2 \pm 1.6$ \\
\hline Milkweed Canyon Profile 1 & WWLS-MW3 & 9.1 & $0.3 \pm 1.2$ & $24.5 \pm 4.6$ & $10.7 \pm 0.8$ & - \\
\hline Milkweed Canyon Profile 1 & WWLS-MW2 & 14.6 & $2.2 \pm 0.6$ & $85.9 \pm 2.3$ & $5.6 \pm 1.7$ & $32.9 \pm 0.4$ \\
\hline Milkweed Canyon Profile 1 & WWLS-MW1 & 18.3 & $2.1 \pm 1.0$ & $77.4 \pm 1.6$ & $15.1 \pm 0.9$ & $35.3 \pm 0.7$ \\
\hline West Water Canyon & WWLS-WW5 & 3 & $6.9 \pm 0.2$ & $462.9 \pm 0.8$ & $52.9 \pm 0.6$ & $28.4 \pm 1.1$ \\
\hline West Water Canyon & WWLS-WW4 & 6 & $0.3 \pm 1.4$ & $116.5 \pm 1.0$ & $32.5 \pm 0.8$ & $37.3 \pm 1.8$ \\
\hline West Water Canyon & WWLS-WW3 & 9 & $10.6 \pm 1.2$ & $438.4 \pm 1.1$ & $98.0 \pm 1.1$ & $24.3 \pm 0.9$ \\
\hline West Water Canyon & WWLS-WW2 & 12 & $2.8 \pm 0.3$ & $462.9 \pm 0.8$ & $4.4 \pm 1.9$ & $33.5 \pm 0.4$ \\
\hline
\end{tabular}

All errors are presented as percent (\%) $1-\sigma$ of \% and ppm elemental concentrations. 